\title{
İkinci Dünya Savaşı Sırasında Alman Denizaltılarının Karadeniz'de Batırılmaları ve Askerî Personelin Türkiye'de Zorunlu Misafirliği
}

\section{The Sinking of German Submarines in the Black Sea During World War II and the Mandatory Accommodation of Military Personnel in Turkey}

\author{
Umut C. KARADOĞAN* (1)
}

*Öğr. Gör. Dr., Sinop Üniversitesi, Boyabat Meslek Yüksek Okulu, Sinop, Türkiye

ORCID: U.C.K. 0000-0003-1197-5156

Sorumlu yazar/Corresponding author: Umut C. Karadoğan,

Sinop Üniversitesi, Boyabat Meslek Yüksek Okulu, Sinop, Türkiye

E-posta/E-mail: umuttarih@hotmail.com

Başvuru/Submitted: 11.03.2021 Revizyon Talebi/Revision Requested: 19.03.2021

Son Revizyon/Last Revision Received: 29.07.2021

Kabul/Accepted: 09.08.2021

Atıf/Citation: Karadoğan, Umut C. "İkinci Dünya Savaşı Sırasında Alman Denizaltılarının Karadeniz'de Batırılmaları ve Askerî Personelin Türkiye'de Zorunlu Misafirliği." Yakın Dönem Türkiye Araştırmaları-Recent Period Turkish Studies 40 (2021): 29-64.

https://doi.org/10.26650/YTA2021-895339
ÖZ

II. Dünya Savaş1 sırasında Türkiye'nin yerleşik olduğu stratejik coğrafya etrafında yaşanan hadiseler neticesinde başta İngiltere ile Amerika Birleşik Devletleri ve zaman zaman da Almanya, Türkiye'ye karşı sert politikalar uygulamaya çalışmışıtır. Almanya'nın Sovyetler Birliği'ni yok etme planının bir parçası olarak kurguladığı Barbarossa Harekâtı çerçevesinde denizaltılarını Karadeniz'e kara ve nehir yoluyla ulaştırma çabası, ardından burada yaşadıkları başarısızlıkların neticesinde Ruslara teslim olmamak için denizaltılarını batırmaları, sözü edilen denizaltı askerî personelin karaya çıktıkları sırada yakalanmaları, enterne edilip daha sonra Türkiye'nin farklı kamplarında zorunlu misafirliğe tabi tutulmaları, dönemin Türk hükûmetinin takip ettiği hukuki süreç, Alman askerlerine karşı takındıkları tavır, bu askerlerinin mübadele biçimleri, Türkiye'nin savaşa ve savaşın taraflarına bakış açısı bu çalışmanın konusunu oluşturmuştur.

Anahtar Kelimeler: II. Dünya Savaşı, U-bot, Alman Askerî Personeli, Enterne, Mülteci Kampları

\section{ABSTRACT}

During the Second World War, as a result of the events that took place around the strategic geography of Turkey, the United Kingdom; the United States of America, and, from time to time, Germany tried to implement harsh policies against Turkey. This study focuses on the following themes: Germany's efforts to transport its submarines to the Black Sea by land and river within the framework of Operation Barbarossa, which was designed as a part of its plan to destroy the Soviet Union; Germany's sinking of its submarines in order not to surrender to the Russians as a result of the failures it experienced there; the capture of the aforementioned submarines' military personnel when they landed, were 
interned, and then subjected to compulsory stay in different camps in Turkey; the legal process followed by the Turkish government of the period; the attitude of the Turkish government toward German soldiers; the exchange method of these soldiers; and Turkey's viewpoint regarding the war and parties of the war.

Keywords: Second World War, U-boat, German Military Personnel, Internment, Refugee Camps

\section{Extended Abstract}

The parties of the second-largest war on Earth were spread across three continents. The Republic of Turkey, which was not a party to this war, did not have the military, social, or economic ability to keep the war going. Therefore, it chose to pursue a policy of impartiality toward the Allied and Axis states.

The warring states were following new strategies to use the straits that belonged to Turkey, and they organized conferences to attract the Turkish government to the war. Despite these pressures, up until the last three months of the war, the Turkish government managed to maintain its neutrality.

Germany's invasion policy against Soviet Russia, with the increase in the violence of the war, turned to primary and secondary areas. At the breaking point of the war, the German military authorities determined the Black Sea and Crimea to be their strategic fronts. They started activities in line with the increase in the number of fronts throughout the region and the determination of different strategies.

There were two main reasons why Hitler attached special importance to the Black Sea and Crimea. The first of these was to reach the oil fields in the Caucasus, and the second was to prevent the Russians from dominating the Black Sea. Germany had to bring Turkey under its control to exert political, social, and military pressure. For this reason, the Germans started an operation aiming for the domination of the area.

Germany, which was unable to use the straits under Turkish sovereignty during the war years, and the Axis powers, which were being influenced by it, implemented the Barbarossa Plan that they had developed against the Soviet Union. The Germans required to use the Turkish straits to implement this plan, and they were unlikely to follow the Montreux Convention on the Straits.

The Germans first landed six U-boats in the 30th Fleet on a land route, and then took to the Black Sea to envelop the Soviets stationed there. After delivering major losses to the Soviets in the Black Sea, six German U-boats were sunk toward the end of the war. 
Meanwhile, Romania was separated from the Axis powers under Soviet pressure, making the Black Sea a center of action with significant losses for the Germans.

Following successive attempts to defeat the Russians, German officers in the stationary sea planned to sink their submarines in Turkish territorial waters and reach into their country from the Aegean coasts under a decree from their headquarters. German soldiers who landed were soon after arrested by Turkish military authorities, interned, and hosted in the camps in the country. The military and civilian refugees of different countries were also collected in these camps. The Germans were first held in Beyşehir and then in Isparta after 1944.

German soldiers had the opportunity to survive after being interned in Turkish camps. Although the Turkish government had endeavored to provide camps with military-level conditions for visiting soldiers, some setbacks were experienced because of the economic, social, and political conditions of the period. Military personnel from different countries, especially German Navy personnel, also tried to reduce the negative impact of war by reaching out to the people in their camps.

During their stay in Anatolia, German soldiers lived not as refugees but as guests. The Turkish government, which did not go to war until 1944, tried not to change the status and conditions of the soldiers in the camps even after they were officially involved in the war. However, the Allies divided Germany into occupation zones, and it surrendered to the United States, and the Union of Soviet Socialist Republics. As a result of these developments, the status of the international organizations in Turkey had to change. 


\section{Giriş}

1939 yılı Türkiye için pek çok yeniliğin başlangıcı olan bir zaman dilimiydi. Kısa süre önce kurucu liderini kaybeden ülke, çok geçmeden kendisini dünya ile birlikte yeni bir savaş çemberinin içerisinde buldu. Tek parti döneminin yaşandı̆̆ bir yönetim anlayışında Türkiye Cumhuriyeti, savaşa müdahil olmayarak toprak bütünlüğünü korumay1 amaçlamıştı. Buradaki asıl maksat kesinlikte "tarafsızlık" değil, savaşa hiçbir biçimde müdahil olmamaktı. Çünkü henüz savaştan çıkmış ve yıpranmış bir milleti on altı yılın ardından tekrar savaş ortamına sokmak sosyal, siyasi ve iktisadi sıkıntılar yaratacağından savaşa girilmemesi daha doğru bir tavır olacaktı. Mihver ve Müttefik Devletler, Türkiye'nin içerisinde bulunduğu jeopolitik konumundan ötürü ülkeyi kendi taraflarında mücadeleye sokabilmek amacıyla yoğun bir gayret içerisine girmişlerse de iki taraf da bunda başarılı olamamıştı.

Dönemin hükûmeti, mutlak surette savaşın dışında kalmak için bir çaba sarf ederken diğer yandan savaşa müdahil olma ihtimalini göz ardı etmemişti. Bu sebeple 1939 yılında Almanya'dan 150 milyon Reichsmark ${ }^{1}$ değerinde askerî mühimmat, silah ve teçhizat siparişi verilmişse de savaş süreci içerisinde bunların birçoğunu teslim alınamamıştı. ${ }^{2}$ Ayrica Türkiye, yaşanan gelişmeler üzerine herhangi bir başat Avrupa devleti ile (İngiltere, Fransa) sorun yaşamamak adına “yardım antlaşmaları” imzalamayı da ihmal etmedi. ${ }^{3}$ Buradaki maksat, karşılıklı iş birliğinin devamlılı̆̆ını temin edebilmekti. Fakat 1940 yılında İtalya'nın Yunanistan'a, Almanya'nın ise Macaristan ve Romanya'ya saldırmasından ve devamında 1941 yılında Balkan devletlerinin birçoğunun Alman tesirine girmesinden, başta Türkiye olmak üzere İngiltere ve Sovyetler Birliği de endişelenmişti. Türkiye, yaşadığı bu endişeyi giderebilmek için Almanya ile Haziran 1941 'de bir "Dostluk Antlaşması" imzalamış ve şimdilik Almanya'nın saldırı eyleminin önüne

1 Reichsmark, Almanların dönem itibarıyla kullandığı para birimi.

2 Krupp, Gutehoffnungshütte, Philipp Holzmann AG., Siemens-Bau Union, Julius Berger Tiefbau AG. firmalarından Gölcük Askerî Limanı'na 30.000.000 mark; Krupp ve Döneberg/ Hamburg Dinamit Anonim Şirketi'nden 50 bin adet kovan (7,5/42'lik) ve 50 atımlık sevk barutu; Germania (Krupp) Şirketi'nden 3 adet denizaltı ve 20 adet Krupp topunun $(15 \mathrm{~cm})$ sadece 3 adeti Türkiye'ye teslim edilmiştir. 12 adet Skoda topu (21 cm'lik) ve 6 adet Skoda obüsünden (24 cm'lik) sadece 3 adedi gönderilmiştir. 5 adet modern askerî uçak, 60 adet Messerschmitt-109 avcı uçağı ve 8 adet Heinkel-111 savaş uçağı sipariş edilmiştir. Cemil Koçak, Türk-Alman Illişkileri 1923-1939. İki Savaş Arasındaki Dönemde Siyasal, Kültürel, Askeri ve Ekonomik İlişkiler, Ankara, Türk Tarih Kurumu Basımevi, 1991, s. 55, 188-196; Hüsnü Özlü, İkinci Dünya Savaşı'ndan Günümüze Türkiye'de Savunma Sanayii'nin Gelişimi 1939-1990, İzmir, Dokuz Eylül Üniversitesi, Atatürk İlkeleri ve İnkılap Tarihi Enstitüsü, Yayımlanmamış Doktora Tezi, 2006, s. 27.

3 İngiltere ve Fransa ile 19 Ekim 1939'da Ankara'da bir ittifak antlaşması imzalanmıştır. Şevket Süreyya Aydemir, İkinci Adam, C.II, İstanbul, Remzi Kitapevi, 2000, s. 142. Türkiye ile İngiltere arasında 12 Mayıs 1939 tarihinde Türkiye’yi "Barış Cephesi'ne” bağlayan ortak bir deklarasyon yayınlanmıştır. Ali Fuad Erden, İsmet İnönü, Ankara, Bilgi Yayınevi, 1999, s. 214. 
geçmeyi başarmıştı. ${ }^{4}$ Fakat bu dönemde Almanya'da iktidarda olan Adolf Hitler'in "Lebensraum" olarak bilinen, doğal sınırları dışında yaşayan Ari ırka mensup toplumların kendi hâkimiyetinde birleştirilmesi ve yeni topraklarda oluşturacakları "yaşam alanlarının" çevresinde tüm nüfusunun iş birliğine dayanan politikayı yürürlüğe koymuş olması sebebi ile siyasi algı çoktan değişmişti. ${ }^{5}$

İşte bu siyasal alg1 içerisinde, Almanya'nın varlığ 1 için stratejik bir değeri olan Rusya'yı istila etmenin kod adı olan Barbarossa Harekâtı, Adolf Hitler için "hayati” önem taşıyordu. Hitler'in etrafındaki strateji uzmanları, Kafkasların ve Karadeniz'in hâkimiyetinin anahtarı olarak harekâtın devreye konulmasını istemişlerdi. Böylece II. Dünya Savaşı'nın en geniş çaplı askerî harekâtlarından birisi olan Barbarossa, 22 Haziran 1941 tarihinde başladi. ${ }^{6}$ Harekâtın öncelikli hedefi, Rumen petrol yataklarını tehdit eden ve Sovyet hava üslerinin olduğu Kırım’ın elde edilmesiydi; çünkü bölgede ciddi bir hava üstünlüğü mevcuttu. ${ }^{7}$ Adolf Hitler 12 Ağustos’ta Kırım’ın ele geçirilmesini için ordularına emir vermiş; Alman Silahlı Kuvvetleri Yüksek Karargâhı da 21 Ağustos'ta harekete geçmişti. ${ }^{9}$

Savaşın devam ettiği süreçte Sovyetler Birliği’nin daha sıkı abluka altına alınması konusu gündeme geldiğinde, İstanbul ve Çanakkale boğazları ile Doğu Akdeniz bölgesinin denetiminin elde edilmesi Almanlar için son derece önemli bir duruma gelmişti. Boğazların 1936 yılında imzalanan Montreux Sözleşmesi ile Türkiye'nin denetimine geçmiş olması üzerine Boğazları kullanarak donanma güçlerini Karadeniz'e sokma imkânını azaltsa da Adolf Hitler, 5 Aralık 1941 tarihinden Almanların çekildiği 1944 yılının yaz aylarına kadar geçen sürede kurmaylarıyla birlikte sözü geçen denize ulaşabilmenin farklı yol ve stratejilerini derinlemesine kurgulamaya başlamıştı. ${ }^{10}$

4 Türkiye Büyük Millet Meclisi Zabıt Ceridesi (TBMMZC), Birleşim: 69, Devre: 6, İctima: 2, Cilt: 19, 25.6.1941, s. 164, 168, 170, 172, 192-195; Kahraman Gürbüz, “İkinci Dünya Savaşı'nda Balkanlardaki Gelişmeler ve Türkiye'nin Tutumu”, Uludağ Üniversitesi Fen-Edebiyat Fakültesi Sosyal Bilimler Dergisi, C.8, S.13, Bahar 2007, s. 371-372.

5 Sebastian Haffner, Hitler Üzerine Notlar, çev. Hulki Demirel, İstanbul, İletişim Yayınları, 2019, s. 14.

6 Peter Antill-Peter Dennis, Stalingrad 1942, Osprey Publishing, Oxford, 2007, s. 7; Gerry Kearns, "Imperial Geopolitics: Geopolitical Visions at the Dawn of the American Century", Companion to Political Geography, Oxford, Blackwell, 2003, s. 173-187.

7 Erich von Manstein, Kaybedilen Zaferler, Kara Kuvvetleri Komutanlığı İstanbul, Askeri Basımevi, 1962, s. 205.

8 David M. Glantz, Operation Barbarossa Hitler's Invasion of Russia 1941, Port Stroud, The History Press, 2011, s. 279.

9 David M. Glantz, Operation Barbarossa..., s. 281.

10 İbrahim Artuç, İkinci Dünya Savaşı, C.II, İstanbul, Kastaş Yayınları, 2003, s. 30-34; Liddell Hard, B. H., II. Dünya Savaşı Tarihi, C.II, çev. Kerim Bağrıçık, İstanbul, Yapı Kredi Yayınları, 1998, s. 518. 
II. Dünya Savaşı'nın sonlarına doğru Karadeniz'de yaşanan tüm olumsuzluklara rağmen Almanlar, direnişlerini 1944 yılında Sovyetler Birliği'nin Romanya'yı işgal etmesi ve onları taraf değiştirmeye zorlamasına kadar sürdürmüştür. ${ }^{11}$ Hatta bu direniş, Köstence' deki Alman üssünde bulunan 6 denizaltıdan üçünün (U-9, U-18, U-24) Rus kuvvetler tarafından batırılıp kalan denizaltıların (U-19, U-20, U-23) mürettebatının da Köstence' den kaçıp sığınacakları bir liman bulamamalarına kadar devam etmiştir. ${ }^{12}$

Almanlar, artık savaşı kazanacaklarına olan inançlarını yavaş yavaş kaybetmeye başlayınca denizaltılardan üçünü Türk Hükûmeti'ne satmayı teklif etmiş; fakat dönemin Türk yetkilileri Montreux Boğazlar Sözleşmesi esaslarını ihlal etmek istemediklerini beyan edince Alman Deniz Kuvvetleri'nin komuta kademesi, daha farklı bir askerî strateji üzerinde durmuş ve Karadeniz' de sıkışan, kurtulma ihtimali kalmayan, seyir hâlindeki üç denizaltı ile mürettebatına Türk kıyılarına giderek orada denizaltılarını batırıp kendilerini de karaya çıkarmaları emrini vermiştir. ${ }^{13}$

\section{II. Dünya Savaşı Yıllarında Almanya'nın Balkanlar ve Karadeniz'deki Faaliyetleri}

II. Dünya Savaşı'nın ilk yıllarında Müttefik Devletler içerisinde en kısa sürede teslim olanlardan biri, 22 Haziran 1940 tarihinde imzaladığı ateşkes ile Fransa olmuştu. Yapılan ateşkesle Fransa, Alman işgalini kabul etmiş ve İngiltere, Batı Cephesi'nde önemli bir destekten mahrum bırakılmıştı. Fransa taarruzundan istediği sonucu alan Almanya'nın, yeni oluşan şartlar karşısında iki tehdit unsuru kalmıştı. Bunlardan birisi İngiltere bir diğeri ise Sovyetler Birliği’ydi. Askerî alanda yıpranan İngiltere'nin devam eden süreçte Almanya ile tek başına mücadele potansiyeli mevcut değildi. Bu olumsuzluğa rağmen Başbakan Winston Churchill yönetimindeki İngiliz Kabinesi, Almanya ile savaşmak için bir kara cephesinin açılmasının zorunlu olduğunun da bilincindeydi. Almanlar ise iki cephede savaşmamak için öncelikle İngiltere'nin savunma hattını kırmak amacıyla 1940 yazı süresince hava akınları tertip etmişti. ${ }^{14} 1940$ yılının yaz aylarında havada devam eden yoğun çarpışmayı Luftwaffe'ye (Alman Hava Kuvvetleri) karşı zor da olsa İngiliz Kraliyet

11 Yonca Anzerlioğlu, "Hamdullah Suphi'nin Kaleminden Romanya'da Komünist Hareket”, Ankara Üniversitesi Türk İkılap Tarihi Enstitüsü Atatürk Yolu Dergisi, S.37-38, 2006, s. 13.

12 Hüseyin Muşmal-Hasret Gümüş, “II. Dünya Savaşı Yıllarında Beyşehir'de Bir Enterne Kampı (Hitlerin Askerleri Beyşehir'de)", Tarihin Peşinde-Uluslararası Tarih ve Sosyal Araştırmalar Dergisi, S.24, 2020, s. 129.

13 Rudolph Ardent, Türklerin Alman Hükûmeti tarafindan yapilan teklifin reddedilmesinin sebebini ABD Hükûmeti'nin Türkiye üzerindeki etkisine bağlamıştır. Rudolph Ardent, Letzter Befehl, Versenken, Verlag, Berlin, E.S. Mittler, 2003, s. 260.

14 James Lucas, Reich! World War II Through German Eyes, London, Grafton Books, 1990, s. 185. 
Hava Kuvvetleri (Royal Air Forces) kazanınca Almanların İngiltere'ye çıkarma yapma şansı da kalmamışt. ${ }^{15}$

İngiltere'nin bu noktadaki varlığı, doğuda Sovyetler Birliği'ne karşı en geniş cephesini açan Almanya'yı rahatsız etmişti. Buna karşılık Almanlar, havadan yapamadıklarını denizden yapabilmek için U-botlarla İngiltere'yi Kuzey Atlantik Okyanusu'nda hızla abluka altına almışt. ${ }^{16}$ Ayrıca Hitler, 28 Eylül 1940’tan sonra silahlanma stratejini de değiştirmişti. Hatta İngiltere'yi işgal planı gerçekleşmeyince kurmaylarından Sovyetler Birliği’nnin istilasına yönelik bir silah programı hazırlanmasını istemişti. ${ }^{17}$

22 Haziran 1941'de başlayan Barbarossa Harekâtı, bu anlamda silah stratejisinin tam anlamıyla yürürlüğe konulduğu ilk harekât olmuştur. Adı geçen bu harekât, zamanında tamamlanmadığı takdirde güçlenme firsatı bulacak olan İngiltere'nin savaş cephesindeki varlı̆̆ 1 yeniden artabilir ve Almanlar için sıkıntı yaratabilirdi. Çünkü savaşa Müttefik Devletlerin yanında girecek bir Amerika Birleşik Devletleri (ABD), İngiltere'yi yeniden yarım cephe statüsüne kavuşturabilir ve açılacak farklı yerlerdeki tali cephelerle Almanların Rusya'da yapmayı planladığı harekâtı baltalayabilirdi. Bu sırada Sovyetler Birliği'nin idarecileri de gelen tehlikenin farkındaydı. 1939-1940 yılları arasında Fin ordusuna karşı güçlükle kazandıkları Pirus zaferinin ardından ordularında gün yüzüne çıkan silahlanma ile örgütlenme tarzındaki sorunların çözümü için yoğun çaba içerisine girmişlerdi. Tüm bunlar olurken Almanlar, Sovyetler Birliği’ndeki gelişmeleri de yakından takip etmiş; Avrupa'nın batısından merkezine kadar uzanan coğrafyada egemen olmaları sebebiyle Sovyetlerin askerî ve stratejik gücünün önünü alabilmenin firsatını doğrudan onların üzerine kurgulayacakları Barbarossa Harekâtı ile sağlamayı ve müttefiklerin de aynı yolla teslim olmalarını temin etmeyi amaçlamışlardı. ${ }^{18}$

Almanların Sovyetler Birliği'ni teslim alabilmesi, Fransa Savaşı'nın ardından ittifaka katılan İtalya'nın ciddi desteğini almasına bağlıydı. Ancak İtalyanların 1940 sonbaharında tek başına iki farklı cephede Yunanistan ve Mısır'da yaptıkları askerî harekâtta

15 Almanlar, ilk aşamada İngiltere'ye çıkarma yapma düşüncesini (Denizaslanı Harekât1-12 Ekim 1940) Barbarossa Harekâtı kararını aldıktan sonra ertelemiş ve 1941 baharına kadar yapılmayacağını açıklamışlardı. Alman Hava Kuvvetlerinin (Luftwaffe) İngiltere'de aldı̆̆ı yenilginin ardından 1941 baharında hava saldırıları seyrelmiş, 10 Mayıs 1941'den sonra da tamamen durmuştu. Çünkü Almanlar, Barbarossa Harekâtı için hava filolarının çoğunu doğuya aktarılmıştı. Liddel Hart B.H., II. Dünya..., s. 114-116; Burak Çınar, “İkinci Dünya Savaşı'nda Almanya'nın İki Cepheli Savaş Sorunu”, Güvenlik Stratejileri Dergisi, C.10, S.20, Ocak 2014, s. 166.

16 Martin Gilbert Churchill, Türkiye İş Bankası Kültür Yayınları, İstanbul, 2011, s. 813; Roy Conyers Nesbit, Ultra Versus U-Boats, South Yorkshire, Pen\&Sword Military, 2008, s. 94.

17 Bu durumda bombardıman uçaklarının ve çıkarma gemilerinin üretimini yüksek miktarlarda cephane üretimi almıştır. Edward N. Peterson, An Analytical History of World War II (Volume 1), New York, Peter Lang, 1995, s. 207.

18 Burak Çınar, “İkinci Dünya...”, s. 167-168. 
hezimet yaşaması, Almanya’yı destek noktasında fazlasıyla tedirgin etmişti. Sözü edilen bu tedirginlik, Libya'daki İtalyan kuvvetlerinin çoğunluğunun bertaraf edilmesi sebebiyle Libya'nın her an düşme tehdidi ile karşı karşıya kalmasıydı. Libya'da yaşanan bu gelişme, İtalya'daki siyasi mücadeleyi de hızlandırmış; rejimin değişmesi tehlikesi gündeme gelmişti. Ayrıca Almanların Kuzey Afrika’ya destek vermesi hem İngiltere’yi Doğu Cephesi'nden uzak tutmak için siyasi bir manevra hem de petrole kısa yoldan ulaşmak adına atılan bir adımdı. Almanların stratejisi başarılı olursa ödülü, Süveyş ve Orta Doğu petrolleriydi ama Almanların stratejileri başarısız olursa da İngilizlerin kara gücünü Sovyetler Birliği’ni dize getirene kadar Avrupa'dan uzak tutacaklardı. Böyle bir durumda Akdeniz'in tamamen İngiliz Kraliyet Ordusu'nun kontrolüne geçmemesi için Almanlar, Şubat 1941 'den itibaren Akdeniz'e önemli miktarda askerî kuvvet sevk etmek zorunda kalmıştı. ${ }^{19}$

Aslında İtalyanlar için Balkanlar'daki askerî gelişmeler bekledikleri gibi gelişmemişti. İngilizlerin müttefiki olan Yunanların kuvvetli bir direnç göstermesi, İtalyanları Arnavutluk'a kadar çekilmeye zorlamıştı. Bu noktada Churchill daha stratejik davranarak ve Almanların İtalyanların yardımına koşacağını öngörerek Türkiye, Yunanistan ve Yugoslavya'dan oluşan bir Balkan cephesi oluşturmak maksadıyla harekete geçmiş ve 3 Mart 1941'de ilk İngiliz asker kafilesini Yunanistan'a göndermişti. ${ }^{20}$ Bunun üzerine Almanlar, 6 Nisan 1941'de karadan ve denizden hizla Bulgaristan, Macaristan, Yunanistan ve Yugoslavya'ya yönelik bir harekât başlatmış; 1 Haziran'da Girit de dâhil olmak üzere bütün Balkan coğrafyasının önemli bir kesimini ele geçirmişti. ${ }^{21}$

Tabiidir ki Almanların Avrupa'da başlattı̆̆ı ve özellikle Balkan ülkelerine kadar uzanan seferleri, Türk Hükûmeti'ni de endişelendirmişti. Hatta endişenin boyutu öyle bir seviyeye ulaşmıştı ki dönemin hükûmeti, önlem olarak Trakya sınırına yakın yörelerdeki bazı stratejik köprüleri imha etmiş²2; ayrıca İstanbul ve çevre şehirlerin bazılarında karartma uygulamıştı. ${ }^{23}$ Ankara'daki olumsuz havayı fark eden Alman Büyükelçisi Franz von Papen, iki hükûmet nezdinde girişimlerde bulunarak liderlerin iletişime geçmesini sağlamıştı. ${ }^{24}$

19 Trumbull Higgins, Winston Churchill and the Second Front, New York, Oxford University Press, 1957.

20 Winston Churchill, Yugoslavia and Greece, Memoirs of the Second World War, Boston, Houghton Mifflin Books, 1991, s. 420 .

21 Burak Çınar, “İkinci Dünya...,", s. 169.

22 İsmet Binark, Türk Parlamento Tarihi, TBMM-VI. Dönem, C.II, Ankara, TBMM Vakfı Yayınları, 2004, s. 1418.

23 Hava Taarruzlarına Karşı Işıkların Söndürülmesi ve Karartılması Hakkındaki Nizamname, Kararname No: 2/10346, T.C. Sıhhat ve İçtimai Muavenet Vekâleti, Hudud ve Sahiller Sıhhat Umum Müdürlüğü, Ankara, Receb Ulusoğlu Basımevi, 1939.

24 İsmail Soysal, Türkiye'nin Siyasal Antlaşmaları, (1920-1945), C.I, Ankara, Türk Tarih Kurumu Yayınları, 2000 , s. 645. 
Gerçekleştirilen tüm iletişime rağmen Almanların Bulgaristan ile anlaşarak Yunanistan sınırına birliklerini yığması, Türkiye'de tepkiyle karşılanmıştır. Adolf Hitler de ortaya çıkan tedirginliğin önüne geçebilmek adına Millî Şef İsmet İnönü’ye bir mektup göndererek Almanya'nın Türkiye'ye karşı herhangi bir tehdidinin söz konusu olmadığını, Yunan topraklarında artan İngiliz tehdidi sebebiyle Balkan coğrafyasına seferler düzenlendiğini açıklamış ama yine de Türkiyeıyi İngiliz birliklerine karşı uyararak onlara karşı takınılacak olumlu bir tavrın geri dönülmesi mümkün olmayacak sonuçlar doğurabileceği tehdidini şu sözlerle mektubuna eklemişti: “...Bulgaristan'a doğru ilerleyen Alman Ordusunun kara unsurlarının, Türk sınırına kadar ilerleyecek olmasının maksadı hakkında yanlış bir anlaşılmanın olmaması maksadıyla Türk sınırından uzak

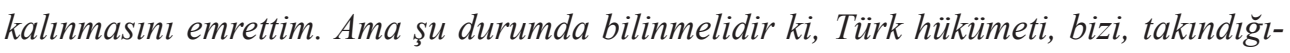
mız tutumumuz ile ilgili başka bir karar vermeye mecbur edecek faaliyetlerde bulunmasın’.25 Buna mukabil İsmet İnönü'nün cevabi yazısı da yine Adolf Hitler'in takındı̆ğ üsluba yakın biçimde şu sözleri içermişti: "Biz inanıyorduk ve bugün de hâlâ inanıyoruz ki, ortada Türk ordularıyla Alman ordularını karşı karşıya getirecek bir sebep yoktur. Ve Almanya, Türkiye'nin emniyetinin ve istiklâlinin gereklerine karşı anlayışlı davrandiğ müddetçe böyle bir felâket meydana gelemez". ${ }^{26}$ İnönü ile Hitler arasındaki mektuplaşmalar, 18 Haziran 1941 tarihine kadar devam etmiş ve Almanya'nın teklifi ile bir dostluk antlaşması imzalanmasıyla neticelendirilmiştir. ${ }^{27}$ Gerçekleştirilen antlaşma her ne kadar Türkiye'nin İngiltere ve Fransa ile yaptığı ittifak anlaşmasıyla çelişkili bir

25 “Hitler ile İnönü’nün 1941 Mart'1ndaki Mektuplaşmaları”, Radikal, 08 May1s 2010, s. 15.

26 İsmet İnönü’nün yazdığı mektup ise “...Alman Devleti Şansölyesi ve Führerinin, benden -kendisinin Alman tutumu hakkında yaptığ gibi- Türk görüşünü samimi ve gerçeklere uygun bir şekilde anlatmamı arzu ettiği intibaını edindim. Dünyanın içinde bulunduğu ciddi durum, halklarının karşısında sorumlu olan liderlerden, öyle bir lisan kullanmalarını istemektedir ki, bu, yakın veya uzak istikbalde ortaya çıkacak olaylara "yalandır" diye damgalanmaya mahkûm olmasın. Mesajınızı bilhassa bu bakımdan memnuniyetle karşıladım. Ekselânslarının bu cevap yazısının muhteviyatında iki memleketlerimiz arasındaki anlayışa dayanan münasebetlerin muhafazası için tek temeli teşkil eden... gayretinin ifadesini bulacă̆ından eminim. Ekselânslarının mesut teşebbüsüyle aramızda vâki olan fikir teatisi, muhakkak ki, Türk-Alman münasebetlerinin normalleştirilmesine ve iyileştirilmesine yardımcı olacaktır”. "Hitler ile İnönü’nün 1941 Mart'ındaki Mektuplaşmaları”, Radikal, 08 Mayıs 2010, s. 15.

27 TBMMZC, Birleşim: 69, Devre: 6, İctima: 2, Cilt: 19, 25.6.1941; “Türkiye Cumhuriyeti ile Alman Reich'1 Arasında 18 Haziran 1941 Tarihinde İmza Edilen Muahedenin Tasdikine Dair Kanun”, Kanun No: 4072, Resmî Gazete, S.4849, 2 Temmuz 1941, s. 1273. "1 Mart 1941 Saat 1.00 Dışişleri Bakanlı̆̆ Şifre Bürosu N:128 Türkiye Cumhurbaşkanı, Ekselâns Bay İsmet Inönü/Ankara Bay Başkan, Alman Hükûmetinin arzusu hilâfina ve İngiltere ve Fransa'nın 3 Eylül 1939'daki savaş ilânı kararı ile Alman halkına empoze edilen savaşta, Alman Reich 'ının şu sıradaki hedefi, Avrupa kıtasında Ingiliz nüfuzunu bertaraf etmektir... Bu bakımdan Ekselâns, size, Yunan topraklarına yerleşme yolundaki Ingiliz tedbirlerinin gitgide tehditkâr bir mahiyet aldiğ ş̧ sırada, bu şartların gerektirdiği muayyen mukabil tedbirleri almaya karar verdiğimi açıklamak isterim. Bu sebeple Bulgar Hükûmetinden, Alman Silâhlı Kuvvetleri'nin bir kısım birliklerine, bu yoldaki belirli emniyet tedbirlerini uygulamak için müsaade etmesini rica etmiş bulunuyorum. Şu kayıtla ki, Türk hükûmeti, bizi, bu tutumumuzda bir değişiklik yapmaya mecbur edecek tedbirlere tevessül etmeyi lüzumlu görmesin”. Muzaffer Deniz, "Hitler Dönemi Türk-Alman Anlaşmaları”, The Journal of Science (SOBIDER), Y.2, S.2, Mart 2015, s. 94. 
durum ortaya çıkarmışsa da dönemin hükûmeti ülke menfaatleri doğrultusunda savaş dışı kalmak pahasına tarafsızlık adına antlaşmayı imzalamıştır. ${ }^{28}$

Antlaşmayı Almanya adına Franz von Papen, Türkiye adına ise Şükrü Saracoğlu imzalamış ve sürecin başlamasıyla birlikte imzalanan antlaşmaların etkisi büyük olmuştur. Yaşanan bu gelişmeden sonra Adolf Hitler, 22 Haziran 1941 tarihinde Barbarossa Harekâtı'nı başlatmıştır. Bu harekât, tarihin en büyük taarruzlarından birisi olurken Almanların Sovyetler Birliği’ne hücum etmesiyle birlikte Türkiye, kuzeyden gelen tehdidin etkisinden bir süreliğine de olsa bu taarruz sayesinde kurtulmuştur. Türklerin Rus baskısından çekinmesindeki en önemli sebep, Stalin'in Kars ve Ardahan'1 topraklarına katmak isterken bir de İstanbul ile Çanakkale boğazlarını üs olarak talep etmesinden kaynaklanmıştır. ${ }^{29}$

Almanlar, yaptıkları hava taarruzunun aksine Balkanlarda İngilizlere karada ve denizde nefes aldırmamış; her iki cephede de ağır darbe indirerek bu coğrafyadan uzaklaştırmış ve Barbarossa Harekâtı'nda İngiliz tesirini en aza indirmiştir. Bu sebeple denilebilir ki İngilizlerin Balkanlarda cephe açma girişimi, Norveç’te olduğu gibi Almanların yararına olmuştur. ${ }^{30}$ II. Dünya Savaşı'nın ilk cephesi olan Polonya'dan açılan Doğu Hattı, savaş sonuna değin mücadelenin devam ettiği bir alandır. Çünkü Barbarossa Harekâtı, istila politikasının son durağıdır.

Sovyetler Birliği'nin ivedilikle işgalini amaçlayan Barbarossa Harekâtı'nın başarılı olması için Sovyet kıyılarının mutlak surette abluka altına alınması gerekmekteydi. Gerçekte Sovyetlerin Karadeniz kıyılarının da ablukada tutulması önemli bir sorundu. Buna sebep, Türkiye'nin savaşa müdahil olmaması ve Montreux Boğazlar Sözleşmesi gereğince Boğazların Türkiye'nin denetiminde kalmasıydı. Bu sırada Alman denizaltılarının Boğazlar yoluyla Karadeniz'e geçme durumu da ortadan kalkmıştı. Almanlar, içinde oldukları durumu aşabilmek adına çeşitli girişimlerde bulundular. Bunlardan

28 İsmail Soysal, Türkiye'nin..., s. 645.

29 Almanlar, Reichstag'ta 3 Ekim 1941 tarihinde, dünya kamuoyuna Vyaçeslav Molotov’un Sovyetler adına Türkiye'nin olası işgalinde kendilerinden destek istediklerini de ilan etmiştir. Winston Churchill, 2. Dünya Savaşı Hatıraları Tek Başımıza Mücadele 1940, İstanbul, Özgün Yayınevi, 2005, s. 342.

30 Burak Çınar, “İkinci Dünya...”, s. 170. 
belki de en önemlisi Türkiye'ye sattıkları “Ay Sınıfı” Atılay ${ }^{31}$ ile Saldıray’1 ${ }^{32}$ dönemin hükûmetinden satın almayı teklif etmeleriydi. Bu teklif Türkler tarafından kabul edilmeyince henüz inşası devam eden Batıray ${ }^{33}$ ile Yıldıray ${ }^{34}$ denizaltılarına müzakere etmeden ve yine iki ülke arasında devam eden antlaşmaların tamamının yükümlülüklerini iptal etmek pahasına müeyyidelerini de yok sayarak el koymayı tercih etmişlerdir. ${ }^{35}$

Adolf Hitler, dönemin Türk Hükûmeti'nin mutlaka Mihver Devletlerin müttefiki olarak II. Dünya Savaşı’na katılacağını düşündüğü için Ankara Büyükelçisi Franz von Papen'e, denizaltılarının ve torpidobotlarının Boğazlardan geçmesine izin verilmesi

31 Atılay denizaltısı, 80 metre boyunda ve 52 mürettebat kapasitelidir. Alman patenti ile ikisi Almanya Kiel'de Krupp Tersanelerinde (Batıray, Saldıray), ikisi Taşkızak Tersanesi'nde inşa edilmek üzere satın alınan ve Türkiye'de inşa edilerek 1939 yılında hizmete giren “Ay Sınıfı” denizaltılardan birisidir. 14 Temmuz 1942 günü entegre edilen teknik mühimmatın denetimi maksadı ile Donanma Komutanlığı tarafından çağırılan denizaltı, saat 14:30'da Çanakkale Morto Koyu istikametinde Binbaşı Sadi Gürcan komutasında seyir halindeyken I. Dünya Savaşı'ndan kalan bir mayına çarparak gövdesinde 1,5 metre çapında bir delik ile batmıştır. Türkiye Cumhuriyeti Cumhurbaşkanlığı Devlet Arşivleri Başkanlığı Cumhuriyet Arşivi (BCA), Fon Kodu: 30.10.0.0, Yer No: 62.419.16, 17.07.1942; BCA, Fon Kodu: 30.10.0.0, Yer No: 171.186.4, 18.07.1942.

32 TCG Saldıray, “Ay Sınıfı” bir denizaltı olup Almanya'nın Kiel kentindeki Germaniawerft Tersanesi’nde inşa edilmiştir. 10 Şubat 1937'de kızağa konulmuş ve 23 Temmuz 1938'de Tümamiral Sait Halman'ın eşi Fatma İclal Hanım (Nemlizade) tarafından kızaktan indirilmiştir. II. Dünya Savaşı öncesinde döneminde sıkıntıları ve Alman deniz personelinin olmaması sebebi ile Alman bayrağı altında Türk personel tarafından 2 Nisan'da İstanbul'a hareket etmiş ve 5 Haziran 1939'da Deniz Kuvvetleri Komutanlığı'nın Haliç Camialtı'ndaki tersanelerinde yapılan törenle Türk donanmasındaki yerini almıştır. Türk Deniz Kuvvetlerinde 1958 yılına kadar hizmet vermiştir. 1.934 ton su üstü ve 1.210 ton sualtı tonajındadır. Mutlu Toy, Savaşta ve Barışta Türkiye’nin Savunması Açısından Denizaltı Gücünün Stratejik Etkileri, Gebze Yüksek Teknoloji Enstitüsü, Sosyal Bilimler Enstitüsü Strateji Bilimi Anabilim Dalı, Yayınlanmamış Yüksek Lisans Tezi, 2007, s. 83.

33 Almanya'da yaptırılan Batıray denizaltı gemisinin nihai sıklet hesabında görülen noksanları incelemek ve masrafları tespit için Almanya'ya heyet dahi gönderilmiştir. BCA, Fon Kodu: 30.18.1.2, Yer No: 85.114.9, 13.01.1939. Almanya'nın Kiel şehrinde Germaniawerft (Krupp) Tersanelerinde 10 Şubat 1937 tarihinde kızağa konmuş, 28 Eylül 1938'de denize indirilmiştir. İnşa edilen bu denizaltı, 1.044 ton su üstü ve 1.357 ton sualtı tonajında olup II. Dünya Savaşı bahane edilerek el konulan iki Türk denizaltısından bir diğeridir. "UA” adıyla 20 Eylül 1939'da Alman donanmasına katılarak II. Dünya Savaşı'nda Orta ve Güney Atlantik'te; 14 Mart 1942'den itibaren de Kuzey Atlantik'te ikmal gemisi olarak hizmet veren denizaltı, 24 Nisan 1942'de Kiel'e dönmüş ve 1 Mayıs 1944'ten itibaren Denizaltılara Karşı Savunma Okulu'nda eğitim verme amacıyla tecrübe denizaltısı olarak kullanılmıştır. 3 Mayıs 1945 'te Kiel Tersanesi'nde kendi kendini batırmıştır. Raşit Metel, Türk Denizaltıcılık Tarihi-I (1960-1970), İstanbul, 1970, s. 545; Mutlu Toy, Savaşta..., s. 83-84.

34 Yıldıray; 9 Eylül 1937 'de Haliç Camialtı Tersanesi’nde törenle kızağa konmuş, 28 Ağustos 1939'da da denize indirilmiştir. II. Dünya Savaşı'nın başlamasıyla birlikte gemi inşa gözlemcisi Alman teknisyen ve mühendislerin ülkeyi terk etmesiyle iki ana dizel motoru Türkiye'ye getirilmemişse de bu durum mevcut hükûmetin girişimleri ile Danimarka'nın Burmeister firmasından 21 Mayıs 1942 tarihinde alınmasına karar verilmesiyle çözüme kavuşturulmuştur. 5 Mart 1943'ten itibaren 2 ana dizel, Turgut Alp maçunası vasıtasıyla gemiye yerleştirilmiş ve 1 Ağustos 1944 tarihinde donanma envanterine girmiştir. 15 Ocak 1946 tarihinde ise görev seyrine başlamıştır. $B C A$, Fon Kodu: 30.18.1.2, Yer No: 98.41.19, 21.05.1942; Ömer Kalaycığlu, Denizaltı ve Filomuz, İstanbul, Deniz Kuvvetleri Komutanlığı, 1990, s. 82; Afif Büyüktuğrul, Cumhuriyet Donanması 1923-1960, İstanbul, Deniz Basımevi, 1967, s. 134. Celal Bayar, Org. Kazım Özalp'e gönderdiği yazıda Atatürk'ün bu gemilere verdiği adları bildirmiştir. $B C A$, Fon Kodu: 30.10.0.0, Yer No: 62.418.5, 19.01.1938; BCA, Fon Kodu: 30.10.0.0, Yer No: 62.418.1, 08.08.1925.

3514 Mayıs 1939 tarihinde Alman Hükûmeti'nin tek taraflı aldığı kararla denizaltıları teslim etmem kararını vermişti. Deniz Kuvvetleri Komutanlığı, Denizlerin Koruyucuları, Ankara, 2003, s. 66. 
karşılığında Türklere 150.000.000 RM değerinde askerî teçhizatın bedelsiz verilmesini söylemiştir. Refik Saydam Hükûmeti teklifi reddedince Adolf Hitler, yeni stratejiler üzerinde çalışmaya başlamıştır. Bu planların en ilgi çekeni, Amiral Erich Raeder'in Kuzey Denizi'nde konuşlandırılan Tip II sınıfı denizaltıları karadan Tuna Nehri'ne taşıması ve parçalar halinde Karadeniz'e indirmesidir. ${ }^{36}$

Almanlar, sözü edilen bu planı 1940’l1 yılların başında düşünmüş ve gerçekleştirebilmek için harekete geçmiştir. Almanlar, ilk aşamada Karadeniz yoluyla Alman ordusunun ihtiyacı olan lojistik desteği sağlamak, nakliyat yapan gemilerini korumak, müttefik Rumenlere yardım ulaştırabilmek için altı denizaltıyı; İtalyanlar da 10. Hafif Filotillalarını kara yolu ve ardından demir yolu vasitasıyla Tuna Nehri üzerinden Köstence'ye ulaştırmıştır. Bu kuvvetler, Sovyetler Birliği’nin Karadeniz'deki deniz gücünü tehdit etmekten uzaktır. Ayrıca Türk Boğazları savaş döneminde kapalı olduğundan (Montreux Boğazlar Sözleşmesi) Mihver Devletler, Karadeniz'de denge kuramamışlardır. Bunun üzerine Hitler, mevcut sıkıntıyı çözebilmek adına Kırım’daki hava üslerini de ele geçirmeyi hedeflemiştir. ${ }^{37}$

Düşünce itibarıyla gerçekleştirilmesi imkânsız bir proje gibi olsa da Alman Kriegsmarine $^{38}$ Komutanı Büyük Amiral Erich Raeder, 30. Filo'ya ait 6 adet U-botun nakliyesinin derhal başlatılması emrini vermiş; süreç dört ay gibi kısa bir sürede ve kritik öneme sahip üç aşamada gerçekleştirilmiştir. Denizaltıların nakliye işlemleri; ilk aşamada Kiel'den (1948 yılındaki adıyla Kaiser Wilhelm Kanalı) nehir yolu ile başlamış, ardından Hamburg'a getirilen denizaltılar Elbe Nehri üzerinden Dresden'e indirilmiş, sonrasında karaya çıkarılıp parçalara ayrılmasının ardından Bavyera eyaletine bağl1 Tuna Nehri yakınlarındaki Ingolstad'a ulaştırılmış, buradan kamyonlarla Galatz’a (Romanya) ve Karadeniz kıyısındaki Köstence'ye kadar 3.300 km yol yaparak hedefe ulaştırılmıştır. ${ }^{39}$

Alman denizaltıları, Karadeniz'e indikten sonra 27 Ekim 1942'den 25 Ağustos 1944'e kadar Sovyet donanmasına karşı 56 operasyon gerçekleştirmiş ve brüt 45 bin 426 grostonluk gemi imha edilmiştir. Adı geçen bu denizaltıların Karadeniz'de insani

36 Bu maksatla U-9, U-18, U-19, U-20, U-23 ve U-24 denizaltıları tercih edilmişti. Burak Çınar, “İkinci Dünya Savaşı'nda Kırım Yarımadası'na Düzenlenen Harekatlar ve Kırım'ın Stratejik Değeri”, Tarih Araştırmaları Dergisi, C.38 S.66, 2019, s. 549.

37 Burak Çınar, “İkinci Dünya Savaşı'nda...,", s. 549-550.

381935 yılında çıkarılan kanunla yeniden düzenlenen Alman ordusunun donanma sınıfıdır.

3916 hızlı hücumbot, 23 mayın temizleme gemisi, 6 denizaltı, 100'den fazla amfibi çıkarma gemisi, 26 denizaltı imha gemisi daha Karadeniz’e Alman donanma gücü olarak indirilmiştir. Timothy C. Dowling, Russia at War, ABC-CLIO Publishing, 2014, s. 129. 
maksatla seyreden Türk teknelerine taarruz ettiği de tespit edilmiştir. ${ }^{40}$ Tüm bu gelişmelerin dışında 25 Ağustos 1944'te Romanya, Müttefik Devletler safına geçip Almanya’ya savaş açınca Karadeniz'deki denizaltıların üçü (U-9, U-18, U-24) Sovyet donanması tarafından bertaraf edilmiştir. Geriye kalan 3 denizaltı da bölgede kısa manevralar icra ettikten sonra Boğazlardan ve Karadeniz'den çıkamayacağını fark edince durum merkeze bildirilmiştir. Dönemin Alman Hükûmeti de Alman Deniz Kuvvetleri Komutanlığı Denizaltı Filosu Amirali Karl Dönitz' ${ }^{41}$ denizaltıların Türkiye kıyılarında personel kurtarıldıktan sonra batırılmasını emretmiştir. ${ }^{42}$

Karadeniz'de Rus saldırıları ve Romanya'nın kıyı şeridini kapatması ile çıkış noktası kalmayan üç Alman U-bot komutanı, Türk kıyılarının 40 mil açığında U-19 denizaltısında, 10 Eylül 1944 tarihinde saat 18:00'de bir araya gelmiş; toplantı 20:00 sularına kadar devam etmiştir. ${ }^{43}$ Denizaltı personelinden karaya çıkacaklar ile denizaltıları batıracak personel, eylemin gerçekleştirileceği koordinatların tespitini tamamlamış ve bu koordinatlara yönelmiştir. Denizaltıyı batıracak personel; akşam saatlerinde yalnızca elektrik motoru kullanarak, aydınlatma olmaksızın ve lastik botlar vasitasıyla karaya yönlenmişlerse de gittikleri yön, kendilerinden önce karaya gönderdikleri personelin

40 "Kara Sularımızda Bir Hadise”, Vatan, S.1325, 8 Ağustos 1944, s. 1, 3. Almanların Türk kıyılarına sadece denizaltılarıyla değil, zaman zaman uçakları ile de saldırdıkları tespit edilmiştir. Bunlardan birisi de 4 Alman taarruz uçağının, ocak ayı içerisinde Marmaris sahillerine bomba atıp, makineli tüfekle ateş açmalarıdır. İçişleri Bakanlığı'nın 13.01.1944 tarih ve 1/210 sayılı kapalı telgraf yazısı, BCA, Fon Kodu: 30.10.0.0, Yer No: 232.563.13, 26.01.1944; Sunay Akın, Önce Çocuklar ve Kadınlar, İstanbul, Türkiye İş Bankası Kültür Yayınları, 2009, s. 38. 3 Ağustos 1944 tarihinde Almanların, Karadeniz (Köstence) üzerinden İstanbul Boğazı'na geçmeye çalışan ve 1.200'ün üzerinde Yahudi taşıyan üç Türk bandıralı tekneye (Bülbül, Morina, Mefkure) saldırdığı; hatta bunlardan Mefkure'yi içerisindeki 300'den fazla mültecisiyle batırdığı iddia edilmişse de ilerleyen yıllarda Mefkure ile ilgili anlatılanların gerçeği yansıtmadığ ve sicilinde 40 net ton yazan, 75 beygirlik, 1929 yılı yapımı, 694 numarayla İstanbul Limanı'na kayıtlı bu teknenin Rusların SC 215 denizaltısı tarafından batırıldığı anlaşılmıştır. H. Esra Danacıoğlu, "Mefkure Faciası”, Toplumsal Tarih Dergisi, S.44, 1997, s. 8-13.

4116 Eylül 1891 tarihinde Berlin'de dünyaya gelen Karl Dönitz, I. Dünya Savaşı yıllarında Breslau’nun mürettebatından birisiydi. 1914 yılında Breslau'nun Osmanlı'ya ilticası ile Osmanlı donanmasında deniz subayı olarak görev yaptı. Kraus Karl Dönitz, Goeben ve Breslau'nun Deniz Seferi, çev. Mustafa H. Cümbüş, Ankara, Orient Yayınları, 2013, s. 74-76. Savaşın bitimi ile Alman ordusundaki yerini alan Dönitz, 1 Ekim 1939'da tümamiral rütbesi ile denizaltılar komutanlığına getirilmiş, 1 Eylül 1940 yılında da koramiral rütbesine yükselmiştir. Dönitz, bundan sonra var gücü ile yeni bir denizaltı filosunu kurmak adına çaba göstermeye başlamıştır. Hitlerin en yakın komutanlarından olan Karl Dönitz, 1937-1939 yılları arasında Kuzey Denizi'ne ilişkin denizaltı taktik planlarını (Wolfpack=Kurt Kapanı) hazırlayıp geliştirmiştir. Bu planlar ile Alman denizaltıları 1939-1942 yıllarında oldukça önemli başarılar elde etmiştir. Dönitz, 1942 yılına ulaşıldığında oramiral olmuş ve 30 Ocak 1943 tarihine kadar da denizaltı filosu komutanlığını yürütmüştür. Aynı ay içerisinde Büyükamiral ve Deniz Kuvvetleri Başkomutanı Amiral Erich Raeder'in yerine geçerek rütbenin ve makamın yeni sahibi olmuştur. Nazi Almanya'sında Hitler'in ölümünün ardından Mareşal Wilhelm Keitel'in, 8 Mayıs 1945 yılında teslim antlaşmasını imzalamasıyla Dönitz de 23 Mayıs 1945'te, Flensburg'da Müttefiklere teslim olmuştur. Ayrıca Adolf Hitler'in intiharının (30 Nisan 1945) ardından 20 gün boyunca Flensburg Hükûmeti namına Almanya Cumhurbaşkanlığı'nı yürütmüştür. Michael L. Hadley “Grand Admiral Dönitz (1891-1980): A Dramatic Key To The Man Behind The Mask”, The Northern Mariner/Le Marin du Nord, C.X, No.2, Nisan 2000, s. 7-20.

42 Rudolph Ardent, Letzter..., s. 260.

43 Rudolph Ardent, Letzter..., s. 215-216. 
gittiği kıyı şeridinin aksi istikametindeki kuzey kıyı şeridi olup karaya üç deniz mili uzaklıktadır. U-23 ve U-20, aralarındaki anlaşmaya müteakip 10 Eylül 1944 tarihinde ilk önce gizli belge, silah ve mühimmatı ardından da kendini batırırken; U-19 denizaltıs1, 11 Eylül günü saat 23:15 civarında Zonguldak’ın Kilimli-Filyos ilçeleri açıklarında yine kendi personeli tarafından batırılmıştır. ${ }^{44}$

Bundan sonra ekibin ilk hedefi, Kocaeli Yarımadası üzerinden Marmara Denizi'ne ulaşmak; orada mümkün olursa terk edilmiş bir tekne temin ederek deniz yoluyla Akdeniz'e varmaktır. Bu amaç için I. Dünya Savaşı'nda müttefik oldukları topraklarda üzerlerinde askerî kıyafetleri, silahları ve 4-5 günlük erzakları olduğu halde; birbirlerinden bağımsız olarak ve bölgenin coğrafi özelliklerinden de istifade edip ormanlık araziden geçerek tedirgin biçimde bulundukları mevkiin içlerine doğru ilerlemişlerdir. Kısa bir süre içerisinde ve birer gün arayla çevre eşrafı tarafından fark edilerek alıkonularak Türk güvenlik güçlerine teslim edilmişler ve 1945 yılının sonuna kadar tutulacakları özel kamplara nakil işlemleri başlamıştır. ${ }^{45}$

44 Rudolph Ardent, Letzter..., s. 213-214, 250, 340. "Denizaltılarımızı Batırıyoruz”, Milliyet, 5 Eylül 1989, s. 11. Bazı kaynaklarda denizaltının Filyos sahili açıklarında olduğu ifade edilmektedir. U-19'un Zonguldak Ereğlisi Kilimli-Filyos sahili arası, 3 deniz mili açığında, 300-400 metre derinlikte, 41,34 kuzey, 31,50 doğu istikametinde; bazı kaynaklarda da 41,16 kuzey, 31,426 doğu istikametinde olduğu iddia edilmektedir. "U-19 Uboat Submarine Wreck" (Çevrimiçi), http://kaanaltin.com/uboat19eng.html, 13.10.2020. U-20 denizaltısı Sakarya'nın Karasu ilçesinin 2,5 km açığında, 41,16 derece kuzey, 31,25 derece doğu koordinatlarında; bazı kaynaklarda da 41,10 kuzey, 30,47 doğu istikametinde olduğu iddia edilmektedir. "U-20 Uboat Submarine Wreck" (Çevrimiçi), http://kaanaltin.com/uboat20eng.html, 13.10.2020. Kule derinliği 18 metre, dip derinliği 23 metrede 35 derecelik açılla sola doğru yatık halde, torpido kapakları ve periskopu açık vaziyette; U-23 denizaltısının ise Ağva'nın 2 deniz mili açı̆̆ında, 41,11 kuzey, 30,02 doğu istikametindeki derinlikte konuşlanmış olduğu tespit edilmiştir. "U-23 Uboat Submarine Wreck" (Çevrimiçi), http:// kaanaltin.com/uboat23eng.html, 13.10.2020; "U20 Batık Denizalt1-Sakarya”, 8 Şubat 2013 (Çevrimiçi), https://www. kulturportali.gov.tr/turkiye/sakarya/gezilecekyer/u20-batik-denizalti, 07.10.2020; "Şile-Ağva Açıklarında II. Dünya Savaşı'ndan Kalma Denizaltı Bulundu”, 1 Şubat 2019 (Çevrimiçi), https://www.ntv.com.tr/galeri/sanat/sile-agvaaciklarinda-2-dunya-savasindan-kalma-denizalti-bulundu,N67sn9kcwU-yOax-JuMOpw, 08.10.2020; “Hitler'in Kayıp Filosu Karadeniz Kıyımızda”, 4 Şubat 2008 (Çevrimiçi), https://www.hurriyet.com.tr/gundem/hitler-in-kayip-filosukaradeniz-kiyilarimizda-8160783, 08.10.2020. Bazı kaynaklarda bu konum 41,16 kuzey, 31,26 doğu olarak verilirken 41,11 kuzey, 30,00 doğu olarak veren kaynaklar da mevcuttur. "U-20 Uboat Submarine Wreck" (Çevrimiçi), www. kaanaltin.com/uboat20.html, 13.10.2020.

45 Rudolph Ardent, ava çıkan köy ahalisi tarafından tek başına yakalanmıştır. Ayrıca takımı ile zaman içerisinde yürüyüş mesafesi açılmış ve bir gün sonunda da bir kısmı ele geçirilmiştir. Hatta Ardent ilk ele geçtiğinde köylülerce Rus casusu zannedilmiştir. Rudolph Ardent, Letzter ..., s. 215, 225, 227. Başmühendis Georg Stober'ın grubu 11 Eylül sabahı, IWO grubu aynı günün öğleden sonrasında Türk yetkililere yakalanırken; 12 Eylül Salı öğleden sonra Başdümenci Heinz Bierwirth bir grup askerî personel ile aynı akşam geç saatlerde, II. IWO grubu ise Teğmen Kratzenberg ile birlikte güvenlik güçlerinin eline geçmiştir. 13 Eylül 1944 Çarşamba sabahı erken saatlerde Rudolph Ardent'in de yakalanması ile birlikte U-23 ekibi tamamen ele geçirilmiştir. Rudolph Ardent, Letzter..., s. 241; Hariciye Vekâleti'nin Kızılay Cemiyeti Genel Merkezi'ne 18.09.1942 tarih ve 30804/838 (14459) sayılı yazısı, Kızılay Genel Merkezi Arşivi, Kutu: 2599, Dosya: 1942/9-4. 


\section{Alman Askerî Mültecilerin Gözaltı Kampı Günleri}

Dünya üzerinde mültecilik meselesi, yüzyıllar öncesine dayanan kitlesel bir hareket olmasina rağmen ülkelerin bunu bir sorun olarak kabul etmesi ancak sert, yoğun ve bilinçli bir eyleme dönüştüğü I. Dünya Savaşı yıllarında olmuştur. Uluslararası örgütler ve birçok devlet bir araya gelerek konuyla ilgili görüş ve önerilerini içeren toplantıların ve organizasyonların ardından hazırladıkları uluslararası antlaşmalar ile sözleşmeleri dünya kamuoyunun bilgisine sunmuşlardır. Bu minvalde II. Dünya Savaşı’nın ardından kurulan Birleşmiş Milletlerin öncelikli sorunlarından birisi olan mültecilik, cemiyet tarafindan; "Siyasi, dini, sosyal birtakım sorunlarla veya ırki sebeplerle öz vatanın terk etmek zorunda kalmış kişi”"46 olarak tanımlanmıştır.

Türkiye Cumhuriyeti ise bu soruna 14 Haziran 1934 tarihinde, 2510 sayılı İskân Kanunu'nun 3. maddesi ile bir çözüm üretmiş ve "Türk devletinin sinırlart içerisinde iskân maksadıyla değil, bir zorunluluk hali ile geçici olarak siğınanlara mülteci denir." ${ }^{47}$ ifadesini kullanmıştır. Ancak mültecilerin "yerleşmek" istediklerini yazı ile ilgili kurum ve kuruluşlara bildirmeleri durumunda "göçmen" statüsü verilerek işlemlerinin takibinin yapılması ve vatandaşlık haklarının tanınması kararı alınmıştır. Bu kanuna 14 Nisan 1930 yılında çıkarılan, 1580 sayılı Ek Yasa'da; “Belediyelerin, Türk ile yabancı ayırımı yapmaksızın, hizmetlerini noksansız olarak mültecileri de kapsayarak yapması gerektiğ $i^{\prime \prime 8}$ kararı alınmıştır.

Tüm bunların dışında 11 Ağustos 1941 tarih ve 4104 sayılı "Muharip Yabancı Ordu Mensuplarından Türkiye'ye İltica Edenler Hakkında Kanun" ile Türkiye Cumhuriyeti Devleti’ne sığınan muharip yabancı ordu mensuplarının ülke arazisine intikal ettikleri süreden itibaren memleketlerine iade olacakları zamana kadar geçen sürede görülecek her türlü işlemler ve tabi olacakları esaslar, mezkûr kanunla belirlenmiş olup yetkili makamın hükûmet olduğu belirtilmiştir. ${ }^{49}$

10 Mart 1942 tarihinde son şekli verilen idari talimatnameye göre de her türlü ilticada bulunulan mahal, olay yeri olarak kabul edilmiştir. Mezkûr mahalde idari ve askerî üç kişiden mürekkep bir heyetin tertip edeceği ilk soruşturmanın ardından ilticanın ve

46 J. Read, Mülteciler Meselesinin Mahiyeti ve Alınmakta Olan Tedbirler, çev. Gülgin Gönenç, Ankara, Türkiye Amme İdaresi Enstitüsü, 1959, s. 1; Yılmaz Altuğ, Devletler Hususi Hukuku Bakımından Mülteciler, İstanbul, İstanbul Üniversitesi Hukuk Fakültesi Yayını, Sermet Matbaası, 1967, s. 8-24.

47 “İskan Kanunu”, Kanun No: 2510, Resmî Gazete, S.2733, 21 Haziran 1934, s. 4003.

48 "Belediye Kanunu”, Kanun No: 1580, Resmî Gazete, S.1471, 14 Nisan 1930, s. 8821

49 “Muharip Yabancı Ordu Mensuplarından Türkiye’ye İltica Edenler Hakkında Kanun”, Kanun No: 4101, Resmî Gazete, S.4887, 15 Ağustos 1941, s. 1553. 
mültecinin statüsü doğrultusunda askerî mülteciler bekletilmeden mutlaka kamplara gönderilmiştir. Siviller ise durumlarını gösterir bir tutanakla bulundukları yerin mülki makamına teslim edilmiştir. Toplu ilticalarda mülteciler, yukarıdaki prosedürler fazla takip edilmeksizin ivedilikle ve kimse ile temas ettirilmeden gözaltı kamplarına intikal ettirilmişlerdir. Yapılan toplu ilticalarda, mutlak surette tertiplenen Emniyet ve İçişleri Bakanlığı tahkikatları neticesinde tespit edilen, şüphelenilen veya asker olduğunu ispatlayan mülteciler geç de olsa askerî kamplara alınmıştır. ${ }^{50}$

II. Dünya Savaşı yıllarında Türkiye, askerî anlamda müdahil olmasa da zaman zaman savaşın farklı yüzüyle karşı karşıya kalmıştır. Bunlardan birisi de Türkiye'ye çeşitli vesilelerle sığınan savaş mültecileridir. Savaştan kaçan, ele geçirilen, iltica eden pek çok kişi Kırşehir, Yozgat, Çorum, Beyşehir, Isparta gibi şehirlerde kurulan gözaltı kamplarına yerleştirilmiş ve savaş sonunda mezkûr kampların tasfiyesi yapılana kadar da buralarda tutulmuştur. Isparta ve Tefenni' $\mathrm{de}^{51}$ bulunan kamplardan sadece Alman askerî mültecileri değil İtalyan ve İngiliz mültecileri de tahliye edilmiştir. ${ }^{52}$ Sadece Isparta'daki gözaltı kampında toplam 289 mülteci (34 subay, 109 erbaş ve 146 er) enterne edilmiştir. ${ }^{53}$

Bu arada II. Dünya Savaşı süresince yukarıda adı geçen farklı yörelerdeki kamplarda asker-sivil toplam 341 Alman uyruklu şahıs gözaltına alınmıştır. ${ }^{54}$ Yalnız Konya ve Isparta'da değil Türkiye'nin muhtelif yerlerinde açılan bu gözaltı kamplarındaki görevli personelin buralardaki asker ve sivil mültecilerin ilk aşamada hayatta kalmaları ve ardından da savaşın nihayetinde ülkelerine gönderilebilmeleri için insanüstü bir çaba içerisine girdikleri de tespit edilmiştir. ${ }^{55}$

50 Ahmet Emin Yaman, “II. Dünya Savaşı'nda Türkiye'de Askeri Mülteciler ve Gözaltı Kampları (1941-1942)”, Tarih Araştırmaları Dergisi, C.22, S.33, 2003, s. 144-145.

5131 Aralık 1945 tarihi itirbarıyla halen Isparta'daki kamplarda mülteci tutulan Alman askerlerinin son grubunun da memleketlerine gönderilmesi hususunda İçişleri Bakanlığı tarafından Başbakanlık, Dışişleri ve Genel Kurmay Başkanlığı'na yazı gönderilmiştir. BCA, Fon Kodu: 30.10.0.0, Yer No: 55.368.32, 12.01.1946.

5220 Şubat-22 Mart 1944 tarihleri arasında sadece Alman değil, İtalyan askerî mültecileri de Türkiye'den Suriye, Yunanistan gibi ülkelere sevk edilmiştir. Örneğin İtalyan tebaasına mensup 259 subay, 586 erbaş ve 2.396 er olmak üzere toplamda 3.251 askerî personel sınır dışı edilmiştir. Millî Savunma Bakanlığı'na 24 Mart 1943 tarih ve 12876 sayı ile gönderilmiş yazıdır. BCA, Fon Kodu: 30.10.0.0, Yer No: 55.368.11, 24.03.1944.

53 Isparta'daki mülteci kampının sorumlusu Binbaşı Naci Erda, 17 Mart 1946 tarihli ve 4440 numaralı sayılı yazı ile durumu ifade etmiştir. Kızılay Genel Merkezi Arşivi, Kutu: 2833, Dosya:1947 (Mültecilere Yardım Dosyası).

5422 Temmuz 1946 tarihli ve 15631 numaralı sayılı yazıya göre; gözaltında tutulan Almanlar, ülkelerine dönebilmeleri için öncelikle İzmir Limanı'na gönderilmiş; gemilere binmeden az önce de yanlarına Türk misafirperverliğinin bir nişanesi olarak "yolluk” tabir edilen birer kilo incir verilmiştir. Kızılay Genel Merkezi Arşivi, Kutu: 2833, Dosya:1947 (Mültecilere Yardım Dosyas1).

558 Temmuz 1946 tarihli ve 5164 numaralı sayılı yazılı resmî yazıda enterne durumdaki şahısların “...Türk milletine karşı şükran hisleriyle meşbu oldukları...” ifade edilmiştir. Kızılay Genel Merkezi Arşivi, Kutu: 2833, Dosya: 1947 (Mültecilere Yardım Dosyası). 
Yukarıda sözü edilen Alman denizaltı personelinin ele geçirilmesinin ardından kendilerinin de adlandıracağı gibi bir esaret değil "zorunlu misafirlik" süreçleri burada başlamıştır. Hatta ilk olarak kendilerini rahatlıkla ifade edebilmeleri için kısa süre önce Berlin Askerî Ataşeliği’nde görev yapan Dışişleri Bakanlığı personelinden Necip Sait Tamboy, Alman mürettebatın tercümanlığını üstlenmiştir. Buna mukabil Genelkurmay Başkanlığı, Alman askerî personelinin Türkiye’ye gayriresmî gelişlerinin sebeplerinin tespit edilebilmesi, mezkûr personelin hakkında daha ayrıntılı bilgi sahibi olabilmesi için bir de Yarbay İbrahim Erdaş'1 görevlendirmiştir. ${ }^{56}$

Sorgusu sırasında Yarbay Erbaş, Ardent'e denizaltının satın alınması için Türk Hükûmeti'nin girişimlere başladığını, bu sebeple denizaltının yerinin belirlenmesi hususunda kendisinin destek vermesi halinde maddi anlamda tatmin edici bir durumun ortaya çıkacağını da sözlerine eklemiştir. ${ }^{57}$ Tabiidir ki Alman denizaltı personelinin sorgusu, ilk aşamada karşılıklı güven ortamının oluşmamış olması ve yabancı bir ülkede, herhangi bir resmî prosedür olmaksızın bulunmanın getirdiği gerginlikle oldukça sert geçmiş; hatta Yarbay Erdaş bir ara Alman U-23 subayı Rudolph Ardent'i vurmakla dahi tehdit etmiştir. ${ }^{58}$

Tüm bu gelişmeler yaşanırken dönemin Dışişleri Bakanlığı, Alman muhataplarına 15 Kasım 1944 tarihinde gönderdikleri telgraf yazısında: "09.11.1944 tarihinde, Bolu'nun Akçakoca ilçesinde 2 subay ve 11 erden oluşan bir grup, Kocaeli'nin Karataş bölgesinde 2 subay ve 21 askerden oluşan bir Alman askeri personelin denizaltılarının batması neticesinde kıyıya ulaştıkları ve Türk yetkililere teslim olmalarının akabinde, sorgularının yapılabilmesi maksadı ile en yakın askeri karakola (Sapanca) sevk işlemlerinin ivedilikle tamamlandiğl ve tutukluluk hallerinin devam ettiğ $i "{ }^{59}$ belirtilmiştir.

Ayrıca her şeye rağmen Almanlara Türk ordusu bünyesinde geçmişten gelen bir sayg1 da mevcuttu ki bu durum zaman zaman kendini göstermiştir. ${ }^{60}$ Bunun en doğru örneklerinden birisi de U-23 denizaltı personelinin ilk olarak Sapanca Gölü çevresindeki askerî garnizonda tutulmaları, kampa gönderilmemeleri, 18 Eylül 1944 tarihi itibarıyla kendilerine tahsis edilmiş kompartımanda ve yanlarında erzakları olduğu halde 29

56 Rudolph Ardent, Letzter...., s. 242-243.

57 Yarbay Ertaş, Ardent'e 32 milyon liralık bir teklifin söz konusu olduğunu söylemiştir. Rudolph Ardent, Letzter..., s. 245.

58 Rudolph Ardent, Letzter...., s. 243.

59 Rudolph Ardent, Letzter..., s. 244.

$60 \mathrm{Bu}$ durum Alman subayların ağırlanması, konaklatılması ve iaşelerinin karşılanması noktasında gösterilen nezakette kendisini belli etmiştir. Rudolph Ardent, Letzter ..., s. 246-248. 
askere de ayrı ayrı hediyeler vermek suretiyle Eskişehir'e, oradan Konya-Beyşehir'e gönderilmeleridir. ${ }^{61}$

U-23 denizaltısına bağlı askerî personele Beyşehir'e ulaşmadan önce Adapazarı'nda, U-19 ve U-20’nin mürettebatı da katılmış, ardından tren yolculuğuna 19 Eylül'e kadar birlikte devam etmişlerdir. ${ }^{62}$ Askerî kamyonlarla akşam saatlerinde (19.00) Beyşehir'deki kampa gelen denizaltı mürettebatının dışında aynı zamanda Bulgaristan ve Kırım sınırından kaçan bir grup başıbozuk Alman askerî personeli de getirilince ortamda yoğun bir kalabalık oluşmuştur. Hatta akşam saatlerine gelen bu nakil sırasında kampta alt rütbeli birkaç subaydan başkası olmamasına rağmen düzen sağlanmış, hemen tüm Alman askerî personeline kamptaki gözaltı sürelerinin sonuna kadar kalacaklar1 yatakhane gösterilmiştir. Mevcut personelin yemek ihtiyaçlarını karşılanması için mutfak açılmış ve iaşenin hızlı temini için kampın mutfak görevlilerine takviye olarak Alman subaylardan mutfakla ilgili iki kişi kamp mutfağı hizmetine verilerek kısa sürede yoğun yemek talebinin karşılanmasına destek olunmuştur. ${ }^{63}$ Yaşanan bu durum, Almanların gittikleri yere ne denli hâkim olmak istediklerini gösteren de bir durumdur.

Bunun bir diğer örneği de 20 Eylül sabahı yaşanmış ve Alman subayları, kamp komutanı Binbaşı Naci Erda’ya kampın durumuna ilişkin şikâyetleri ile eksikliklerini bir rapor halinde belirtme imkânını bulmuşlar ve taleplerinin ivedilikle temin edilmesini istemişlerdir. İlk defa yaşanan bu gelişmeye karşın Binbaşı Naci Erda, kampta kaldıkları süre zarfında huzurlarının temini hususunda Ankara'dan aldığı direktifler doğrultusunda ve gereken incelemelerin ardından ihtiyaca binaen iyileştirmelerin yapılacağını subaylara ifade etmiştir. ${ }^{64}$

$\mathrm{Bu}$ arada Alman denizaltı personelinin enterne edildiği kamp, Beyşehir'in pazar merkezine yakındır. Kıraathane, hamam, dükkânlar yani kısacası dönemin sosyal yaşam alanına Almanlar tanık dahi olmuşlardır. Kampın ilk girişindeki büyük bina, Alman subayların konaklaması için tahsis edilmiştir. Alt katta bir yemekhane ve bir çay ocağı

61 Rudolph Ardent, Letzter..., s. 248-250.

62 Ancak Alman U-19 denizaltısından karaya botla çıkanlar hariç 2 subay, 2 astsubay ve 2 er bir gün sonra karaya çıkmıştır. Rudolph Ardent, Letzter ..., s. 250-251. “Alman'a Falaka”, Milliyet, 6 Eylül 1989, s. 11.

63 Rudolph Ardent, Letzter..., s. 253-254. Beyşehir ilçesinde Merkez Otel'de ikamet eden Alman subaylarının iaşe ihtiyacı diğer eratın durumundan farklıydı. Alman üst düzey askerler için pazar yerine yakın, yolun sol kolunda bir restoran ile anlaşılmıştı ki Almanlar buraya "Hasan'ın Zehir Mutfağı” adını vermişlerdi. Devlet üst düzey Alman askerlerin yemek ihtiyacını karşılıyordu. Hüseyin Muşmal-Hasret Gümüş, "II. Dünya Savaşı Yıllarında...”, s. 129. Bu durum, bir süre sonra askerler maaş aldığından kendileri tarafından karşılanmaya başlamıştır. Milliyet, 17 Eylül 1989, s. 11. Hatta verilen alakart yemekleri Kızılhaç'a şikâyet etseler de bekledikleri sonucu alamamışlardır. Rudolph Ardent, Letzter..., s. 257-263.

64 Rudolph Ardent, Letzter..., s. 255. 
mevcuttur. Alman subayların ilk dönemlerde satranç oynamak, kitap okumak ve askerî dersler çalışmak gibi faaliyetleri için tahsis edilmiştir. İlerleyen zamanlarda ise marangozluk yeteneğine haiz olan personel, kendilerine ayrılan atölyelerde, odalarındaki ve koğuşlarındaki ihtiyaca binaen sandık, dolap, masa ve sandalye yapabilme imkânını da bulmuşlardır. ${ }^{65}$ Yukarıda ifade edildiği gibi Almanların bulundukları yerlerde alana hâkim olma gayretlerinin birinde, yerini bilemeyen ve "zorunlu misafirliğin" şartlarını zorlamayı tercih eden bir subay, kamp komutanı ile psikolojik otorite mücadelesine girmiş ve Binbaşı Erda, akılcı birtakım çözümlerle sorunun üstesinden gelmiştir. ${ }^{66}$

Tabiidir ki Türk kamplarında yalnız Alman askerî personeli değil, savaş müddetince Alman ordularından kaçıp batı kıyılarından Türkiye'ye giren pek çok milletten binlerce asker-sivil de enterne edilmiştir. ${ }^{67}$ Mülteci olarak gelen siviller; canlı hayvan, yaşam malzemeleri ve arabaları ile sığınırken askerler ise sorumlulukları altındaki mühimmat,

65 Alman subaylar konakladıkları yere "merkez otel” derken Hasan'ın aşçılık yaptığı yere "zehirli mutfak" adını vermişlerdi. Hatta Ardent, ilk geldikleri zamanlarda tanık olduğu kadınların hamam dişına taşan bir kavgasının, daha sonra öğrendiği Türk sosyal hayatına yakışmayan bir tutum olduğuna; Beyşehir'in, Mustafa Kemal'in modernleşme adına gerçekleştirdiği ilkelere uyma hususunda direniş gösterdiğine de kitabında yer vermiştir. Rudolph Ardent, Letzter..., s. 257-258.

66 Alman Dışişleri Bakanlığı’nın Berlin'den Ankara’ya 24 Ekim 1944 tarihli gönderdikleri belgede Türk kamplarında enterne edilmiş 255 Alman (27 subay, 214 astsubay, 14 denizci mürettebat ve gümrük memuru) olduğunu iddia etmişler ve bunların adlarının ivedilikle adlarının kendilerine bildirilmesini talep etmişlerdir. Rudolph Ardent, Letzter ..., s. 256257.

6730 Eylül 1944 günü Sisam adasındaki son Alman kuvvetleri burayı terk ederek istikametlerini Leros'a çevirirler. Fakat burayı tahliye ederlerken her tarafi da tahrip ederler. Bu arada adaya 3 Alman denizaltısı gelir ve adada kalan az sayıdaki İtalyan, Yunan çeteleriyle çatışır. İtalyan askerlerinden sağ kalan 17 tanesi, Kuşadası'nın Dipburnu bölgesine çıkarak Türkiye'ye iltica etmek istese de kabul edilmez ve sınır dışı edilirler. $B C A$, Fon Kodu: 30.10.0.0, Yer No: 55.368.22, 09.10.1944. Eylül 1943'ün ilk haftası sadece Rodos adasından kaçmak sureti ile Marmaris, Fethiye, Köyceğiz sahillerine iltica eden kişi sayısı 83 subay, 64 küçük rütbeli asker, 220 er ve 200 sivil olmak üzere toplam 567 'dir. Bu mültecilerin içerisinde yaralılar ve bakılmak zorunda olanlar da mevcuttur. "Rodos Yanıyor", Cumhuriyet, 16 Eylül 1943, s. 1. Aynı yılın ekim ayı içerisinde Bodrum limanına sığınan hasarlı bir Yunan torpidosunda 30 ölü askerin naaşları mevcutken; ayrıca 20 yaralı asker de Türkiye'ye iltica etmiştir. "Bodrum Limanına Yaralı Bir Yunan Torpidosu İltica Etti”, Cumhuriyet, 26 Ekim 1943, s. 1. Türkiye'nin batı kıyılarına (Kuşadası, Bodrum, Çeşme, Söke, Fethiye, Marmaris) 5 gün içerisinde (22 Aralık-26 Aralık 1943) 361 erkek, 182 kadın ve 289 çocuktan oluşan sivillere eklenen 5 İtalyan subay, 101 İtalyan er ve 2 Yunan askerî personeli ile toplam 940 mülteci sığınmıştır. 27 Aralık 194311 Ocak 1944 tarihlerinde bu yörelere Sisam ve Söke de dâhil olmuş; 227 İtalyan, 94 Yunan sivil ve askeri, 27 İngiliz ve Amerikalı sivil ile adalardan gelen 18 Türk mülteci ülkeye giriş yapmıştır. $B C A$, Fon Kodu: 30.10.0.0, Yer No: 55.368.1, 05.01.1944. 1944 yılının ilk yarısında (1 Şubat-19 Temmuz) diğer yörelere ek olarak Dikili, Söke, Ayvalık ve Güllük (Küllük) sahillerine 503 Türk, 3.426 Yunan, 137 İtalyan (50 sivil, 87 asker), 191 İngiliz (183 sivil, 3 subay, 5 asker), 10 Amerikalı, 1 sivil Musevi, 2 Alman askeri iltica talebinde bulunmuştur. $B C A$, Fon Kodu: 30.10.0.0, Yer No: 117.814.2, 26.08.1944. 27 Ağustos 1944'te bu sefer Edirne'nin Uzunköprü mevkiinden 188 mülteci iltica talebinde bulunmuştur. Bunlar arasında 90 Türk, 75 çingene, 20 Yunan ve 3 Bulgar mevcuttur. BCA, Fon Kodu: 30.10.0.0, Yer No: 117.815.4, 03.09.1944. 21 Ağustos-1 Eylül 1944 tarihinde Bosna köyünden Türk sınırını geçerek iltica talebinde bulunan çeşitli meslek gruplarından (kaymakamı, jandarma komutanı, mal müdürü, avukat, öğretmen, öğrenci, posta memuru, gazeteci, tüccar...) 29 kişi (20 erkek, 2 kadın ve 7 asker) ve bunu müteakiben Kuşadası, Çeşme, Bodrum çevresinden 205 Yunan (16 çocuk, 27 kadın, 172 erkek), 8 Polonyalı erkek, 1 Amerikalı kadın, 140 Alman (135 asker, 2 subay, 3 sivil) ve 3 de Türk ilk aşamada kamplara alınmıştır. $B C A$, Fon Kodu: 30.10.0.0, Yer No: 117.815.1, 01.09.1944. 
silah ve araçlarıyla sınırlardan giriş yapmışlardır. ${ }^{68} \mathrm{Bu}$ askerî araç ve malzemelerden kullanılabilir olanlar, ilerleyen zamanda Türk Silahlı Kuvvetleri’nin envanterine de kaydedilmiştir. ${ }^{69}$

İşte bu düşünceden hareketle Ankara' daki bürokratik ve askerî makamlar, Alman denizaltı personelinin enterne edildiği kamptaki günlük yaşantıları devam ederken yöreye resmi ya da gayriresmî yollardan temas kurmak maksadiyla zaman zaman heyetler göndermiş; başta subaylara ve sonra da diğer alt rütbedeki mürettebata denizaltıların batırılmasının sebepleri, emrin $\mathrm{BDU}^{70}$ tarafından verilip verilmediği, denizaltıların teknik özellikleri hakkında bilgi almaya yönelik sorgulamalar yapmıştır. ${ }^{71}$

1944 yılında Alman askerî personelinin önemli bir bölümünün yerleştirildiği Beyşehir ${ }^{72}$ kampının fiziksel durumuna bakıldığında; gaz lambaları ile aydınlatılmanın sağlandığı, 1sınmak için soba kullanıldığ 1 , taştan inşa edilen bir bina olduğunda yangın tehlikesinin bulunmadığı ama yangın söndürme tüpünün olmadığ1, yatakhanelerde 130 kişinin barındığından bir süre sonra nefes almanın dahi güçleştiğinden bahsedilirken zaman zaman bu durumun hastalıklara da sebebiyet verdiğinden söz edilmiştir. ${ }^{73}$ Bazı kampların göl veya sulak alanlarda kurulması, sıtma gibi hastalıklara da firsat vermiş; bunların tedavisinde tıbbi imkânlar yetersiz kaldığından askerlerin hastalıkları ilerlemiş ve hatta 20 yataklı kamp hastanesi yeterli

6824 Mayıs 1944 tarihinde Başbakanlık, Dahiliye ve Hariciye vekaletlerine yazılan yazıya göre Şile Limanı'na iltica eden bir adet Alman römorku ile birlikte 64 Alman ve Rumen askerî personel, 26 Mayıs'ta Boğazlar Komutanlığı'na sevk edilmişlerdir. BCA, Fon Kodu: 30.10.0.0, Yer No: 55.368.14, 13.06.1944. Yine 1944 yılının 28 Temmuz-2 Eylül tarihleri arasında Edirne Gümrük Muhafaza Müdürlüğ̈’ne 24 Yunan ile 945 Türk mülteci, beraberlerinde getirdikleri 35 araba ve 285 baş muhtelif hayvanla iltica etmiştir. $B C A$, Fon Kodu: 30.10.0.0, Yer No: 117.815.6, 07.09.1944. 7 Eylül 1944 tarihinde saat 15:15’te, üç motorlu Alman deniz uçağı Atina'dan gelerek İzmir limanına iltica etmiştir. $B C A$, Fon Kodu: 30.10.0.0, Yer No: 55.368.20, 07.09.1944. Sivlingrad-Dimetoka bölgesinden de Almanlar iltica etmişlerdir. BCA, Fon Kodu: 30.10.0.0, Yer No: 117.815.3, 03.09.1944. Kırım ve Dimetoka'dan gelen başıbozuk 160 Alman askerinden sadece bir kısmı Meriç (Maritsa) Nehri'ni geçmeyi başarabilmiş ve bunlar da Beyşehir'deki kampa getirilmiştir. Rudolph Ardent, Letzter..., s. 252.

69 Mevcut Alman Hükûmeti'nin teslim olmasından önce Türk kıyılarında arızalanan "Habicht" adlı bir römorkör ile "Katia" adlı bir motorun, hâlihazırda bir Alman Hükûmeti olmaması hasebi ile savaş ganimeti sayılmasına; fakat Katia'nın arızasının giderilememiş olmasından dolayı Deniz Kuvvetlerinin envanterine alınmamasına 08.06.1945 tarih ve 26957 sayılı yazıyla karar verilmiştir. $B C A$, Fon Kodu: 30.10.0.0, Yer No: 55.368.28, 20.08.1945. Befehlshaber der Unterseeboote (Denizaltı Komutanlığı).

71 Bu arada Türk Hükûmeti ile Amerikan Hükûmeti arasında mültecilerin değil denizaltıların teslimi hususu gündeme gelmiş; fakat Amerikalılar mülteciler konusunda 1srarcı olunca dönemin hükûmeti, askerleri savaş müddetince teslim etmeme kararı almıştır. Rudolph Ardent, Letzter..., s. 260-261.

7220 Aralık 1944 tarihli rapora göre Alman Askerî Enterne Kampı, Konya-Beyşehir'de 268 er-erbaş ve subay kapasiteliydi. Kampın komutanlığını Binbaşı Naci Erda yaparken kampta 14 subay, 124 astsubay, 17 er olmak üzere toplamda 155 kara personeli; 9 subay, 32 astsubay, 20 bahriyeli er olmak üzere toplamda 61 deniz personeli; sınır muhafız birliği ve gümrük personeli 50 er-erbaş, 5 subay olmak üzere toplam 271 Alman vatandaşı kampta enterne edilmiştir. Rudolph Ardent, Letzter..., s. 329.

73 Rudolph Ardent, Letzter..., s. 330. 
olamadığından askerler şehir merkezlerindeki hastanelere nakledilmek zorunda kalmışlardır. ${ }^{74} \mathrm{Bu}$ durum, dönem itibarıyla Türkiye'deki kampların imkânlarının ne denli sınırlı kaldığını ortaya koymuştur.

İlerleyen yıllarla birlikte bulundukları gözaltı kamplarına adapte olan Alman askerî personeli, bir süre sonra sadece kendi ihtiyaçları için değil Beyşehir halkının da ihtiyaçlarının temini noktasında faaliyetlerde bulunmuştur. Bunun örneklerinden birisi, II. Dünya Savaşı öncesi Alman mühendisleri tarafından inşa edilmiş olan ve şehre enerji sağlayan hidroelektrik santralinde meydana gelen arızanın giderilerek şehrin enerji ihtiyacının yeniden sağlanması hususunda olmuştur. Alman askerî personeli tarafindan verilen bu destek, halk ile daha sıcak temas kurulmasına da vesile olmuştur. Ayrıca yaşanan mevcut gelişmeler; kamp içerisinde askerlerin daha rahat hareket etmesine, isteklerinin hızla temin edilmesine, havalandırma ve spor saatlerinin esnetilmesine imkân vermiştir. Buna mukabil Alman denizaltı personelinden 33 kişi bir araya gelerek kamp içerisinde bir dershane kurmuş; Türk dilinin temellerinin öğrenilmesi ve hatta bunun yanı sıra İngiliz dilinin ilerletilmesini sağlayacak eğitim-öğretim faaliyetlerinin başlamasına vesile olmuştur. Ayrıca kamp içerisinde konferanslar ile seminerler tertiplenebildiği gibi bulundukları yörenin tabiat koşullarını keşfedebilmelerine imkân sağlayan araştırma grupları teşkil etmelerine de müsaade edilmiştir. ${ }^{75}$

Bilindiği üzere deniz seviyesinden 1.200 metre yüksekteki Beyşehir, 1940’lı yıllarda henüz bataklıkları ıslah edilmemiş, gölün kenarında bitki yetiştirilemeyen ve yazın Anophilis sivrisineklerinin sıtmaya sebep olduğu bir yer iken; kış aylarında ise bir metre kar altında, mart ayına kadar yolları açılmayan küçük bir Anadolu kasabasıydı ve savaş uzadıkça bu koşullar tahammül sınırlarını zorlamıştı. Savaşın sonlarına doğru ülke genelinde artan iktisadi sıkıntı, fizikî ve sıhhi koşulların hızla bozulmasına sebep olduğu gibi mevcut coğrafi ve iklimsel şartlarının etkisi ile kamptaki 298 askerin üçte biri tropikal sıtma olmuş, 130 kişinin durumu akut atağa dönüşmüştü. ${ }^{76}$ Mali anlamda yaşanan sorunlar, beraberinde ödeneksizliği de getirmiş; bunun neticesinde beslenme hizmetlerinde aksaklıklar görülmüş, uzunca bir süre mevcut durum giderilmemiş, nihayetinde Alman denizaltı personeli de durumu Uluslararası Kızılhaç Heyeti'ne şikâyet etmiştir. Bunun üzerine konuya ilişkin Cenevre'den bir heyetin kampı ziyaret etmesi de

74 Rudolph Ardent, Letzter..., s. 264-332.

75 Rudolph Ardent, Letzter..., s. 262-264. Alman komutanlar, girdikleri yakın temasların ardından Türklerin yaşam biçimlerinin ve temizlik alışkanlıklarının kırsal olması sebebiyle biraz zayıf olduğundan dahi bahsetmişlerdir.

“Anadolu'dan İlk İzlenimler”, Milliyet, 7 Eylül 1989, s. 11.

76 Rudolph Ardent, Letzter..., s. 266. 
sağlanmıştır. Yaşanan mezkûr ziyaretin ardından Alman askerî personelinin kamp şartları, eski düzenin dahi ötesine geçmiştir. ${ }^{77}$

Anadolu'daki gözaltı kamplarında bunlar yaşanırken Türk Hükûmeti, 4-11 Şubat 1945 tarihinde davet edildiği Yalta Konferansı’nda Almanlara karşı Müttefik Devletlerle savaşa girmesi noktasında zorlanmış ve bu tavrın bir neticesi olarak 1 Mart 1945'den itibaren sembolik de olsa savaşa Müttefik Devletler saflarında müdahil olmuştur. ${ }^{78}$ Türkiye, bu süre zarfinda fiilen savaşa müdahil olmamışsa da 24 Şubat günü Beyşehir kampındaki askerlerin yurtdışı ile tek temas noktası olan radyo dinlemesine son verilmiş, subayların maaşları kesilmiş, erlerin maaşlarında ise kesintiye gidilmiştir. ${ }^{79}$

Mevcut şartlar altında Alman denizaltı personelinin ve diğer askerî zevatın kamp içerisinde yaşanan bu sıkıntı karşısında daha fazla zarar görmesini önlemek ve ileride gündeme gelebilecek bir politik sıkıntıyı da engellemek için 1 Kasım'dan itibaren personele Kızılay tarafından 16,5 lira destek parası bağlanmış ${ }^{80}$ ve kamp sakinlerini şartları nispeten daha iyi olan bir yere nakledilmeleri için Ankara'da girişimlerde bulunulmuştur. Sonuçta dört kamp yerinin (Yozgat, Isparta, Niğde, Malatya) adı öne çıkmış, dönemin idari ve askerî yetkilileri de Isparta kampı konusunda anlaşınca 7 Mayıs 1945 tarihinde tüm enternelerin nakil işlemleri, kasaba halkı ve mülki erkânın katılımı ile 17 adet ağır vasıta eşliğinde saat 17:00'de başlamıştır. Konvoy, Konya' da bir süre çadırlarda konakladıktan sonra meşakkatli bir seyahat sonunda 10 Mayıs'ta Isparta kampına ulaşılmış; hatta bu nakil esnasında (8 Mayıs 1945) Alman ordularının Müttefik kuvvetlere teslim olduğu haberi de alınmıştır. ${ }^{81}$

Alman denizaltı personelinin Isparta günleri, Türkiye'nin savaş yıllarındaki iktisadi koşulları düşünüldüğünde biraz daha rahat olmuştur. Enterne edilen askerlerden bir kısmı şehrin girişindeki ilk binaya; diğerleri de belediye ile cezaevi arasındaki parkın yanındaki bloğa yerleştirilmiştir. Kısa süre de Türk halkına olan aşinalığın da tesiri ile sosyal yaşama hızla uyum sağlayan personel, ardından gündelik faaliyetlerine de başlamıştır. Örneğin haftada bir gün, sekiz kişilik gruplar halinde ve bir nöbetçi inzibat askeri

77 Rudolph Ardent, Letzter..., s. 265-266.

78 Rudolph Ardent, Letzter..., s. 261.

79 Buradaki maaş kesintisi Alman askerî personelle alakalı olmayıp ülkenin savaş hazırlıklarından kaynaklanmıştır. "Hitler Selamı Yasaklanıyor", Milliyet, 10 Eylül 1989, s. 13.

80 Aynı zaman diliminde askerlerin gül yağı fabrikasında çalışmalarına, tamirat işleri ile ilgilenmelerine, yöreye yapılacak hastanenin inşaatında mesai yapmalarına dahi izin verilmiştir. "Dalgacı İtalyanlar”, Milliyet, 15 Eylül 1989, s. 11.

81 Rudolph Ardent, Letzter..., s. 267. Kamp şartları bir ara o denli ağırlaşmıştır ki kendilerine dağıtılan ekmeklerden tasarruf ederek kalanını satmışlar; paketi 8 mark olan sigaraları saklayıp daha yüksek bedelle satarak istihkaklarını karşılamaya çalışmışlardır. "Elveda Türkiye”, Milliyet, 12 Eylül 1989, s. 11. 
eşliğinde şehrin tüm dükkânlarından alışveriş yapılabilmiş; bu süre zarfında "pazarlık" kavramı da öğrenilmiş olduğundan denizaltı personeli, esnafın sıkı müşterileri halini almış hatta kahveler dahi ısmarlanmıştır. Bunu haziran ayı içerisinde spor faaliyetlerinin dışarıda park alanlarında ve halkın arasında nöbetçi inzibat eşliğinde yapılması uygulaması takip etmiştir. Nöbetçilerin varlığı hem koruma hem de kaçma girişimlerinin önüne geçilmesi maksatlıdır (Tablo 1). ${ }^{82}$

\begin{tabular}{lcc} 
Gün & Sabah & Öğleden Sonra \\
\hline Pazartesi & Alışveriş̧ & Yürüyüş̧ \\
Salı & Yüzme & Yürüyüş \\
Çarşamba & Park Gezisi & Spor \\
Perşembe & Alışveriş̧ & Yürüyüş \\
Cuma & Park Gezisi & Yürüyüş \\
Cumartesi & Park Gezisi & Spor \\
Pazar & Spor & --- \\
\hline
\end{tabular}

Tablo 1: Alman askerî personelin haftalık bulundukları kamptan süreli “dışarı çıkış” programı

Kampa yerleşilmesinden iki ay sonra (1 Temmuz 1945 tarihinden itibaren) Türkiye'nin Müttefik saflarında savaşa girmiş olmasının da tesiri ile tedbirler sıkılaştırılmıştır. Getirilen tedbirlerden üçü, enterneler için sıkıntılı olmuştur. Bunlardan ilki, subayların istedikleri zaman sair mürettebat ile serbest biçimde iletişime geçmesinin yasaklanmasıdır. Tüm personelin görüşmeleri izne bağlanmış, kamp ziyaretleri güne ve saatlere bölündüğü gibi nöbetçi subay eşliğinde yapılmasına karar verilmiş; ayrıca subay, astsubay ve erlere verilen ödeneklerde düşürülmüştür. Elbette bu durumdan sadece Alman denizaltı personeli değil uzun zamandır onlarla birlikte hareket eden kamp komutanı Binbaşı Naci Erda da etkilenmiştir. ${ }^{83}$

Dönemin gazetelerinde Adolf Hitler'in 24 Aralık 1944 tarihinde başkomutanlıktan feragat ettiği yazılmış ${ }^{84}$; aradan fazla bir zaman geçmeden de 1945 yılı itibarıyla savaş sona ermiş, Reich teslim olmuştur. Kamplardan rahatlıkla çıkabilen Alman askerî personeli, durumu Isparta'da bir çay bahçesinde radyodan öğrenmişlerdir. ${ }^{85}$ Alman askerler için şartlar bozulmuşsa da dönemin Türk Hükûmeti ile askerî yetkililerinin sivil ve

82 Kaçma girişimi Türkiye’nin güney sınırındaki (Suriye) bir kamptan yaşanmış; bu girişimin ardından tedbirler artırılmıştır. Rudolph Ardent, Letzter..., s. 268-271.

83 Rudolph Ardent, Letzter..., s. 271-272.

84 "Beyşehir'de Noel”, Milliyet, 8 Eylül 1989, s. 11.

85 Binbaşı Lorz, Alman komuta heyetine Konya'daki Binbaşı Naci Erda’yı ziyaretin şart olduğunu ama bundan sonra kesinlikle "Führer selamı" verilememesi gerektiğini ifade eden bir konuşma yapmıştır. Akşam yemeğinin ardından 3 subay (Hubert, Henning ve Arendt) yolda Türk subaylarına rastladıklarını, onların kendileri ile samimi şekilde konuştuklarını; hatta savaş müddetince yaptıklarını takdir ettiklerini ifade ettikten sonra İngiliz ve müttefiklere hakaret içeren cümleler dahi sarf ettiklerini söylemişlerdir. "Hitler Selamı Yasaklanıyor", Milliyet, 10 Eylül 1989, s. 13. 
askerî sorumluluk bitmemiştir. Alman komutanlar, hiçbir askerini geride bırakmamak ve tezkerelerine kadar aldıkları sorumlulukları yerine getirebilmek adına ilk olarak konaklanan yerden tahliyelerini temin etmiş; Türk askerî lokali de boşaltılmış ve "savaş mültecilerine" ellerindeki düşük ödenek ile şehir merkezindeki otelde geçici yatakhane tahsis edilmiş olsa da şartlar zamanla daha da kötüleşmiştir. Bu birliktelik hali U-bot personeli arasında hiçbir şartta bozulmamış, kampın son gününe kadar devam etmiştir. $\mathrm{Bu}$ durumun korunmasında Türk sivil ve askerî yetkililerinin gösterdiği olumlu tavrın yadsınamayacağı da bir gerçektir. ${ }^{86}$

Diğer taraftan kamplardaki mültecilerin sahip oldukları teknik ve el becerileriyle sair alanlardaki kabiliyetlerini ülke menfaatleri doğrultusunda kullanmaları düşüncesi gündeme gelmiş, bu hususla ilgili olarak ilk İstanköy ve Rodos adalarından kaçarak Türkiye'ye sığınan İtalyan uyruklu mülteciler (elektrikçi, şoför, motorcu, demirci, tornacı...) üzerinde yoğunlaşılmıştır; fakat il sınırları içerisinde sözü edilen mülteciler gayretle mesleklerini icra etmek istemelerine rağmen teknik sebeplerden ötürü bu durum pek mümkün olmamıştır. ${ }^{87}$ Aynı biçimde ülkenin farklı kamplarında bulunan mülteciler, iş ve çalışma taleplerine vatandaşlık arzularını da iliştirmişlerdir. ${ }^{88}$ Bunun ilk örneklerinde birisi, 20 Ocak 1946 tarihinde Alman uyruklu Ottom Eyer Ernstbannenberg'in Başbakanlığa telgrafla yaptığı müracaattır. ${ }^{89}$

Türk gümrük, liman ve sınırlarına ilticalar 2 Eylül 1944'ten 1945 yılının yaz aylarına kadar devam etmiştir. ${ }^{90}$ Ayrıca Türkiye, ülkeye sığınanlara sadece iaşe ve barınma

86 Rudolph Ardent, Letzter..., s. 273-274.

87 Ulvi Keser, “Arşiv Belgeleri Işı̆̆ında İkinci Dünya Savaşı Sürecinde Türkiye'de Mülteciler ve Esirler Sorunu”, Çăgdaş Türkiye Tarihi Araştırmaları Dergisi, C.VII, S.18-19, 2009, s. 202-203.

88 BCA, Fon Kodu: 30.18.01.2, Yer No: 97.126.11, 11.03.1942; BCA, Fon Kodu: 30.18.1.2, Yer No: 100.85.15, 23.09.1942.

89 BCA, Fon Kodu: 30.10.0.0, Yer No: 124.882.12, 02.05.1945.

90 BCA, Fon Kodu: 30.18.01.2, Yer No: 96.72.13, 12.08.1941. Kuşadası, Çeşme ve Edirne'nin Karaağaç bölgelerinden 2-10 Eylül 1944 tarihleri arasında 90 sivil (57 erkek, 20 kadın, 13 çocuk), 7 Yunan rütbesiz askeri ve 8 İtalyan vatandaşı (6 erkek, 1 kadın, 1 çocuk) ceman 105 kişi Türkiye topraklarına iltica etmiştir. BCA, Fon Kodu: 30.10.0.0, Yer No: 117.815.8, 12.09.1944. 10 Eylül'de Trakya sınırından Filibe Valisi, Sofya Jandarma Komutanı, iki emniyet görevlisi ve bir Bulgar albay iltica etmek istemiş; fakat içlerinden yalnızca albayın talebi kabul edilmiştir. $B C A$, Fon Kodu: 30.10.0.0, Yer No: 117.815.9, 13.09.1944. Marmaris Gümrük Muhafaza Bölük Komutanlığı tarafindan yapılan denetimler sırasında 21 Kasım-23 Kasım 1944 günlerinde Rodos'tan bir balıkçı teknesi ile gelerek Marmaris'e sığınan 7 Yunan ve 513 Türk, toplamda 520 mülteci (BCA, Fon Kodu: 30.10.0.0, Yer No: 117.815.14, 25.11.1944) ile 3 Şubat-17 Şubat 1945 tarihleri arasında yine aynı yere iltica etmeye çalışan 1.172 Yunan, 519 Türk, 62 İtalyan ve 1 Ermeni, toplam 1.754 kişi geçici olarak kamplara alınmıştır. $B C A$, Fon Kodu: 30.10.0.0, Yer No: 117.815.16, 28.05.1945. 
imkânı sağlamakla kalmamış; talepte bulunanlara vatandaş olabilmeleri imkânını da tanımıştır. ${ }^{91}$

Mart 1946' dan başlayarak Alman denizaltı personeli, Isparta'daki kamptan ülkelerine dönüş tarihleri belli olmasa da subaylara tahsis edilen 110 lira ödenek ile kendilerine özel bir takım giyim-kuşam malzemeleri ve sair ihtiyaçlarını almak için girişimlerde bulunmuşlardır. Son olarak 30 Haziran 1946 tarihinde Isparta'daki savaş mültecileri kampının yetkililerce ziyaret edilmesinin ardından 20 Temmuz 1946 tarihinde zorunlu Türkiye misafirliklerini bitirmek zorunda kalmışlardır. ${ }^{92}$

\section{Mülteci Kamplarının Kapatılması ve Sonrasında Yaşanan Gelişmeler}

II. Dünya Savaşı'nın yıkıcı tesirinden kurtulabilmek için çeşitli vesilelerle Türkiye'ye sı̆̆ınmış olan Almanya, Japonya veya adı geçen ülkelerle hâlihazırda savaş durumunda bulunan devletlerin tabiiyetinden mültecilerden sadece askerlik vazifesinde olanlarının uluslararası antlaşmalar gereğince mensubu oldukları ülkelere iade edilmeleri, devlet makamları tarafından kabul edilmiştir. ${ }^{93}$ Hatta bu kamplarda savaş sonrasında da bir müddet gözaltılar devam etmiş; buna rağmen kamp yetkilileri, valilikleri vasıtasıyla mültecilere yardım hususunda daha önce alınan kararların yürürlükte kalıp kalmadığını çözmekte tereddüt dahi etmişlerdir. ${ }^{94}$

Alman askerî personelinin akıbeti konusu bir süre Türk siyasilerinin ve kamuoyunun gündemini oluşturmuş, 16 Temmuz 1946 tarihinde alınan karar gereği personelin galip devletlere teslim edilmesinin siyaseten daha doğru bir tavır olacağına kanaat getirilmiştir. ${ }^{95}$ Bir süre sonra Kırşehir, Yozgat, Çorum, Beyşehir ve Alman denizaltı personelinin de gözaltında tutulduğu Isparta'daki kamplar boşaltılmaya başlanmıştır. Buradaki mülteci ya da gözaltındaki askerî personelin memleketlerine gönderilmeye başlanması ile birlikte sıra U-bot personeline gelmiş ve bir yıl on ay on gün Türkiye'de kalan Hitler'in

91 Türkiye'de yaşama iradesini yetkili mercilere bildiren toplamda 3.130 kişi için Bakanlar Kurulu'nun aldığı 1942 yılının 11 Mart (559), 13 Nisan (271), 23 Eylül 1942 (392); 1943 yılının 8 Eylül (203), 18 Şubat (256), 21 Mart (192), 15 Temmuz (296), 16 Ağustos (445); 1944 yılının 22 Aralık (69), 18 Ocak’ta (85), 5 Mart (77), 12 Mart (22), 26 Nisan (67), 2 Temmuz (60), 23 Ekim (59), 22 Kasım (77) tarihli kararlarıyla Türk vatandaşlığına geçmelerini kabul edilmiştir. $B C A$, Fon Kodu: 30.18.1.2, Yer No: 97.126.11, 11.03.1942; BCA, Fon Kodu: 30.18.1.2, Yer No: 100.85.15, 23.09.1942; $B C A$, Fon Kodu: 30.18.1.2, Yer No: 95.64.9, 25.07.1941. 16.02.1945 tarihli ve 73237/ 16/650/310 say1l ile 1312 sayılı kanunun 5. maddesine göre Bakanlar Kurulu kararı ile Alman uyruklu ve 1890 doğumlu Hertha Arnd, Türk vatandaşlı̆ğına alınmıştır. $B C A$, Fon Kodu: 30.18.1.2, Yer No: 107.106.3, 01.03.1945.

92 Rudolph Ardent, Letzter..., s. 277.

9321 Mayıs 1945 tarihli Bakanlar Kurulu karariyla. BCA, Fon Kodu: 30.18.1.2, Yer No: 108.29.16, 21.05.1945.

94 Muğla Valiliği, Yunan adalarından iltica talebinde bulunan mültecilerin taleplerinin kabulü ve desteğin devamı noktasında İçişleri Bakanlığı’'na müracaatta bulunulmuştur. BCA, Fon Kodu: 30.10.0.0, Yer No: 117.815.17, 14.03.1945.

“Elveda Türkiye”, Milliyet, 12 Eylül 1989, s. 11. 
285 askeri, beraberlerinde Türk askerî yetkilileri olduğu halde Isparta'dan özel bir trenle ve Kızılay'ın verdiği kumanyayla öncelikle İzmir'e götürülmüş; oradan 21 Temmuz 1946 tarihinde yola çıkan "Mersin" adlı bir yolcu gemisine bindirilerek 31 Temmuz günü İtalya'nın batısındaki Toskana bölgesinde bulunan Livorno liman şehrine ulaşmış ve burada Amerikan askerî makamlarına teslim edilmiştir. ${ }^{96}$

Öte yandan savaşın bitimiyle birlikte kampların geleceğinin ne olacağı tartışmaları başlamış ve son olarak Yozgat'taki kamplardan çıkarılarak kısa süreli olarak Deusches Krankenhaus'da (Alman Hastanesi) konaklamaları maksadı ile İstanbul'a gönderilen 15 Alman askeri de ayarlanan bir tütün gemisi ile Almanya'ya gönderilmiştir. ${ }^{97}$

Savaşın sona ermesi ile birlikte kamplarda kalan insanlara uygulanacak hukuki prosedürün şekli ve hitap hususunda birtakım sıkıntılar yaşanmış, bu gelişmeler üzerine dönemin yetkilileri tarafından "Mülteciler Misafirhanesi" adı ile bir çalışma başlatılmıştır. Yapılan çalışmanın ilk uygulaması olarak da Kastamonu'da bir misafirhane açılmış ve Yozgat'taki kampta kalan 53 kişi buraya nakledilmiştir. İlerleyen süreçte Türk vatandaşl1ğına geçenler ve memleketine dönenlerle birlikte Kızılay kampları tasfiye edilmiştir. ${ }^{99}$

96 Millî Savunma Bakanlığı'nın 16.07.1946 tarih ve 711028, 23.07.1946 tarih ve 13248-674-5000 sayılı mütalaası üzerine Bakanlar Kurulu’nun 23.07.1946 tarihli kararı ile Isparta Kamp Komutanı Binbaşı Naci Erda ve Dış İkmal Bürosu Mütercimi Ahmet Emin Mestçioğlu'na 30 gün sürecek yolculukları için gündelik verilmesi de kararlaştırılmıştır. $B C A$, Fon Kodu: 30.18.1.2, Yer No: 111.53.6, 29.07.1946; $B C A$, Fon Kodu: 30.18.1.2, Yer No: 111.55.2, 22.08.1946; $B C A$, Fon Kodu: 30.10.0.0, Yer No: 55.368.32, 12.01.1946. Rusya'da esirken Türkiye'ye kaçan ve Yozgat'taki gözaltı kampına yerleştirilen üç Alman askerin 24 Ekim 1944 tarihinde sınır dışı edilmesine karar verilmiştir. 16 Nisan 1947 tarih ve 12964 sayılı yazıya istinaden BCA, Fon Kodu: 30.10.0.0, Yer No: 55.368.39, 16.04.1947. Yozgat'taki mülteci kamp1 16 Ağustos 1948 tarihinde tamamen kapatılmıştır. 26 Ağustos 1948 tarihli ve 20005 sayılı yazı, Kızılay Genel Merkezi Arşivi, Kutu: 2883, Dosya: 1947 (Mültecilere Yardım Dosyası). Dönemin Alman Hükûmeti adına enterne edilen 9 Yunan askeri, 14 Mart 1946 tarihinde memleketlerine gönderilmek üzere kamptan ayrılır. Isparta Kamp Sorumlusu Binbaşı Naci Erda'nın 17 Mart 1946 tarihli ve 4440 sayılı merkeze gönderdiği yazı, Kızılay Genel Merkezi Arşivi, Kutu: 2883, Dosya: 1947 (Mültecilere Yardım Dosyası). Geminin İzmir'den kalkması için 3 gün beklenmiştir. Buna sebep, diğer kamplardan gelecek enterneler ve merkezden gelen konsolosluk görevlilerinin aile fertlerinin de aynı gemi ile dönecek olmasıdır. Rudolph Ardent, Letzter ..., s. 281-282, 285. Bu arada Alman askerlerine 2 kg zeytinyağı da verilmiştir. “Akçakoca'da Hitler Selamı”, Milliyet, 13 Eylül 1989, s. 13.

97 Rusya'dan iltica eden Martin Zerhoch, Gottlieb Lackert, Günter Wölk ile Kıbrıs'dan Türkiye’ye kanunsuz yollarla giren ve Almanya'nın, Amerikan işgal bölgesine gitmek isteyen Neuman Kurt, Franz Gebert, Georg Boheman, Mauris Bruno, Willy Kühner, Maus Peter, Anton Riedmiller, Karl Grosche, Herbert Gerner, Hans Kirschner, Willy Zollweg ve Ernst Satzky isimli askerler, adı geçen yük gemisi ile ülkelerine gönderilmişlerdir. Kızılay Cemiyeti Genel Merkezi tarafindan hazırlanan 1 Nisan 1949 tarihli ve 5699 sayılı ve ayrıca 6 Nisan 1949 tarihli ve 2113 sayılı yazı, Kızılay Genel Merkezi Arşivi, Kutu: 2883, Dosya: 1947 (Mültecilere Yardım Dosyası); Kızılay Genel Merkezi Arşivi, Kutu: 2883, Dosya: 1944-1949-II (Mültecilere Yardım Dosyası).

9828 Aralık 1948 tarihli ve 64372 sayılı yazı, Kızılay Genel Merkezi Arşivi, Kutu: 2883, Dosya: 1947 (Mültecilere Yardım Dosyas1).

99 Yozgat Emniyet Müdürlüğ̈̈’nden Kastamonu Misafirhane Müdürlüğ̈̈’ne 21 Mayıs 1949 tarihli ve 247 sayılı ile gönderilen yazı, Kızılay Genel Merkezi Arşivi, Kutu: 2883, Dosya: 1944-1949-II (Mültecilere Yardım Dosyası). Burada misafirlere maaş verilmeye devam edilip edilmeyeceği tartışma konusu olmuştur. 25 Mayıs 1949 tarihli ve 8809 sayı ile Kastamonu Mülteciler Misafirhanesi Müdürlüğü’nün Kızılay Genel Başkanlığı'na gönderdiği yazı, Kızllay Genel Merkezi Arşivi, Kutu: 2883, Dosya: 1944-1949-II (Mültecilere Yardım Dosyası). Kampta bulunan misafir sayısının 52 olduğunu kampın müdürü Rıza Tunç’un gönderdiği 6 Haziran 1949 tarihli ve 108 sayılı yazı ile öğrenmekteyiz. Kızılay Genel Merkezi Arşivi, Kutu: 2883, Dosya: 1947 (Mültecilere Yardım Dosyası). 


\section{Sonuç}

Amerikalı ve İngiliz diplomatların dışında Almanlar da Türkleri II. Dünya Savaşı'nda yanlarına çekebilmek için ciddi bir çaba içerisine girmişlerdir. Tabiidir ki bu mücadele, Türkiye'nin içerinde bulunduğu coğrafi konum, yeraltı ve üstü kaynakları ile doğru orantılıdır. Almanların Türkiye planları, diğer devletlerinkinden biraz daha farklıdır. Şöyle ki Almanlar, öncelikle güven ortamı oluşturabilmek için Türkiye'ye taarruz edilmeyeceğine dair Adolf Hitler'in mektubunu 4 Mart 1941 tarihinde Franz von Papen aracılığıyla dönemin idarecilerine ulaştırmış olsa da 1942 yazından sonra kod adı "Gertrude" olan bir operasyon planladıkları yıllar sonra ortaya çıkarılmıştır. ${ }^{100} \mathrm{Bu}$ operasyonda maksat Almanların Sovyet Ruslara karşı başlatmış oldukları "Barbarossa Operasyonu”nun başarıya ulaşmasını temin edebilmek adına Kafkasya’nın güney kanadını güvence altına almak, Azerbaycan petrolüne erişimi garantilemek ve Sibirya gibi zor bir coğrafyada askerin lojistik, enerji gibi ikmal imkânlarını tamamlamaktır.

İşte bu maksatla 30. Denizaltı Filotillası'nı oluşturan altı adet U-bot (U-9, U-18, U-19, U-20, U-23, U-24) Köstence Limanı'ndan Karadeniz’e gönderilmiştir. Denizaltılar, 27 Ekim 1942 tarihinden 10 Eylül 1944 tarihine kadar çoğunluğu Sovyet donanmasına karşı olmak üzere 56 taarruz düzenlemiştir. Bu taarruzların sonunda üç denizaltısını kaybeden (U-9, U-18, U-24) filotillaya bir darbe de 25 Ağustos 1944 tarihinde Rumenlerden gelmiştir. II. Dünya Savaşı'nda Rumenlerin saf değiştirmesi ile Almanlar, sadece Karadeniz'deki ikmal limanlarını değil önemli bir müttefiklerini de kaybetmiştir.

Alman Hükûmeti, bu durumda en azından yetişmiş deniz personelini kurtarabilmek adına dönemin Türk Hükûmeti'ne kalan üç denizaltıyı satmak istese de talebi kabul edilmeyince Alman Denizaltı Komutanlığı tarafından denizaltıların tamamının batırılması ve personelin Türk karasularından kıyıya çıkmaları emri verilmiştir. Alman denizaltı personelinin kendilerini Karadeniz'de Sovyet donanmasından kurtarabilmek adına yaptıkları bu girişim, Türkiye için askerî ve siyasi pek çok olumsuz sonucu olabilecekken dönemin yönetim kademesinin siyasi girişimleri neticesinde, durum Türkiye'nin lehine çevrilebilmiştir.

Buna mukabil Türkiye II. Dünya Savaşı'nda, tüm gayretlerine rağmen uzun süre savaş dışı kalmasına karşın yaşanan gelişmeler doğrultusunda kâğıt üzerinde de olsa

100 "Gerdrud" da denilen bu plan; 1942 yılının yaz ayında hazırlanmış, daha sonra adı değiştirilmiştir. Chris Cummins, "Operation Gertrude: The German Invasion Of Turkey", World At War Magazine, S.49, 2016, s. 1-16; "C Listesine Dahil Olanlar Kimlerdir", Tan, 30 Eylül 1945, s. 1. 
mücadeleye girmek zorunda kalmıştır. Türkiye, savaşta fiilen yer almamasına rağmen yine de olumsuz tesirinden kaçamamış ve çoğunluğu kanunsuz olmak üzere topraklarına sığınan pek çok mülteciyi gözaltı kamplarında uluslararası hukuk kuralları ile antlaşmalar çerçevesinde barındırmıştır.

1939-1941 yılları arasında dönemin hükûmetinin "kanun çıkartıp talimatnameler” hazırlayarak karşı karşıya kaldığı bu mevcut askerî ve sivil mülteci sorununu çözmek adına yoğun bir gayretin içerisine girmesi, uluslararası camiada kendi üzerine yönelecek tepkileri bir nebze de olsa azaltabilmek adına yaptığı girişimlerden başka bir şey değildir.

Söz konusu kanunlar ve talimatnamelere göre ülke güvenliğine zarar vermemek koşuluyla mülteciler arasında asker olanlar dâhil tüm iltica talebi olanların kabul edilmesi, konuya ilişkin gereken tüm hassasiyet ve eşgüdümün sergilenmesi ve ciddi bir insani muamelenin uygulanması esası da benimsenmiştir.

II. Dünya Savaşı'nın başlangıç yıllarında kanunsuz yollardan ülkeye girenler hızla sınır dışı edilebilirken ilerleyen dönemlerde savaşın Türk topraklarına da yaklaşmasıyla artan iltica talebini karşılamanın çaresizliği karşısında mültecileri hızla geldikleri yere göndermek de mümkün olmadığından dönemin hükûmeti, mültecilerin tüm sorumluluğunu da üstlenmek zorunda kalmıştır.

Sorumluluğun hükûmet tarafından kabul edilmesinin ardından iltica edenlerin sınırdan geçtikleri andan itibaren sorgulanması görevi, bu bağlamda yörenin mülki amirine devredilmiştir. Yörenin mülki amirinin başkanlığında toplanan heyet, sorgulama işini üstlenmişse de askerî mülteci oldukları saptanan şahısların sorgulanması durumu hâsıl olduğunda Türk Silahlı Kuvvetleri (TSK) devreye girmiştir. Ayrıca sivil mültecilerin sorgulanmasından önce mensubu oldukları devletin elçilikleri ile temasa geçilmesi, adlarına pasaport çıkartılması ve yapılan görüşmelerden ardından iltica taleplerinin kabul edilip edilmeyeceğine karar verilmesi de yine aynı heyetlere bırakılmıştır. Mülteci kamplarına gönderilen şahısların içerisinden isteyenler ya da kurallara riayet etmeyenler olduğunda hızla sınır dışı edilmesi, içlerinden talep edenlerin resmi işlemlerinin tamamlanmasından sonra vatandaşlığa alınması da yine sözü edilen heyetin görevleri arasındadır.

Gerekli soruşturmaların tamamlanmasının ardından sürekli göz hapsinde tutulacak mülteciler için önce Niğde, Sivas, Ankara, Yozgat, Isparta, Erdek ve Adana'da gözaltı kampları açılarak mülteciler bu kamplara gönderilmiştir. Kamplara sadece Alman değil Fransız, Yunan, Bulgar, Rus, İspanyol, İran, İtalyan, Amerikan ve Iraklı askerler de gönderilmiştir. Bu minvalde aynı alanda bulunmaları sakıncalı görülen ve yabancı devletlerden 
birbirine düşman olan millet veya zümrelere mensup mültecilerin farklı kamplara nakilleri, Dışişleri Bakanlığı ve Genelkurmay Başkanlığı'nın istişareleri ardından Millî Savunma Bakanlığınca düzenlenen tezkire ile sağlandığg da tespit edilmiştir. Mültecilerin zorunlu ikametleri müddetince Türk Ordu Dâhili Hizmet Hükümleri tüm kamplarda uygulanmıştır. Bu arada Türk yetkililer, kampların işleyişinde mültecilerin var olan ihtiyaçlarının daha etkin karşılanabilmesi noktasında, sığınmacıların kendi içlerinden belirledikleri kişileri kamp heyetinin içerisinde yer almasına da müsaade etmişlerdir.

Türkiye Cumhuriyeti Devleti, II. Dünya Savaşı sırasında ülke topraklarına sığınan yabancılara karşı statüsü fark etmeksizin elindeki hemen tüm imkânları seferber etmiştir. Hatta o kadar ki yabancı ülke askerlerinin ikamet ettirildikleri kampların şartlarının -ülkenin içinde bulunduğu siyasal, sosyal ve iktisadi koşullar değerlendirildiğinde- Türk askerine sunulan şartlardan daha iyi durumda olduğu anlaşılmıştır. Özellikle Alman askerî personelinin Türkiye'nin muhtelif yerlerinde bulundukları kamplarda Türkçe öğrendikleri, sosyal ve ekonomik açıdan yerel halkla etkileşimde bulundukları da tespit edilmiştir.

Yaşanan durum da göstermektedir ki Türk Hükûmeti ve halkı, kendisini uluslararası arenada sıkıntıya sokacak bir halde dahi ihtiyaç duyan kişilere -mensubu bulunduğu millete bakmaksızın- yardım edebilmiştir. Yakın dönem Türk-Alman ilişkileri değerlendirilirken üzerinde durulması gereken hususlardan birisi de Türk Hükûmeti'nin 25 y1l önce müttefikken 1940’lı yıllara gelindiğinde işgal tehdidi ile karşı karşıya kaldığ halde, Alman mültecilere zorunlu misafirliklerinde ihtimam göstermesi, müspet bir tavır ve davranış sergilemesi, destek ve yardım sunarak Türk misafirperverliğini sergilemesidir. Bu uluslararası siyaseten de değerli bir harekettir.

76 yıl önce batan söz konusu denizaltıların yerleri günümüzde hemen hemen belirlenmiştir. Adolf Hitler'in Karadeniz'e gönderdiği denizaltılardan Türk kıyılarına yakın batırılanların enkazlarının hepsinin yerinin belirlenmesi hususunda tam anlamıla bir başarı sağlanamamış olsa da Türkiye ve Almanya arasında yapılacak bir iş birliği ile bu tarihî kalıntıların gün yüzüne çıkarılması, geçmişin karanlıkta kalan kısımlarının aydınlatılmasında yararlı olacaktır.

Hakem Değerlendirmesi: Dış bağımsız.

Çıkar Çatışması: Yazar çıkar çatışması bildirmemiştir.

Finansal Destek: Yazar bu çalışma için finansal destek almadığını beyan etmiştir.

Peer-review: Externally peer-reviewed.

Conflict of Interest: The author has no conflict of interest to declare.

Grant Support: The author declared that this study has received no financial support. 


\section{KAYNAKÇA}

\section{Arşiv Kaynakları ${ }^{101}$}

Türkiye Cumhuriyeti Cumhurbaşkanlı̆̆ Devlet Arşivleri Başkanllğı Cumhuriyet Arşivi (BCA)

Kızılay Arşivi

\section{Resmî Yayınlar ${ }^{102}$}

Hava Taarruzlarına Karşı Işılkların Söndürülmesi ve Karartılması Hakkındaki Nizamname, Kararname No: 2/10346, T.C. Sihhat ve İçtimai Muavenet Vekâleti, Hudud ve Sahiller Sıhhat Umum Müdürlüğü, Ankara, Receb Ulusoğlu Basımevi, 1939.

Resmî Gazete

Türkiye Büyük Millet Meclisi Zabıt Ceridesi (TBMMZC)

\section{Süreli Yayınlar ${ }^{103}$}

Cumhuriyet

Milliyet

Radikal

Tan

Vatan

\section{Araştırma Eserler}

Akın, Sunay: Önce Çocuklar ve Kadınlar, İstanbul, Türkiye İş Bankası Kültür Yayınları, 2009.

Altuğ, Yılmaz: Devletler Hususi Hukuku Bakımından Mülteciler, İstanbul Üniversitesi Hukuk Fakültesi Yayını, İstanbul, Sermet Matbaası, 1967.

Antill, Peter-Dennis, Peter: Stalingrad 1942, Oxford, Osprey Publishing, 2007.

Anzerlioğlu, Yonca: "Hamdullah Suphi'nin Kaleminden Romanya'da Komünist Hareket”, Ankara Üniversitesi Türk İnklap Tarihi Enstitüsü Atatürk Yolu Dergisi, S.37-38, 2006. 
Ardent, Rudolph: Letzter Befehl, Versenken, Verlag, Berlin, E.S. Mittler, 2003.

Artuç, İbrahim: İkinci Dünya Savaşı, C.II, İstanbul, Kastaş Yayınları, 2003.

Aydemir, Şevket Süreyya: Ikkinci Adam, C.II, İstanbul, Remzi Kitapevi, 2000.

Beesly, Patrick: Room 40: British Naval Intelligence 1914-1918, London, H Hamilton Press, 1982.

Binark, İsmet: Türk Parlamento Tarihi, TBMM-VI. Dönem, C.II, Ankara, TBMM Vakfı Yayınlar1, 2004.

Busch, Rainer-Röll, Hans-Joachim: German U-Boat Commanders Of World War II: A Biographical Dictionary, translated by Geoffrey Brooks, London\&Annapolis, Greenhill Books\&Naval Institute Press, 1999.

Büyüktuğrul, Afif: Cumhuriyet Donanması 1923-1960, İstanbul, Deniz Basımevi, 1967. Churchill, Winston: 2. Dünya Savaşı Hatıraları Tek Başımıza Mücadele 1940, İstanbul, Özgün Yayınevi, 2005.

Churchill, Winston: Yugoslavia and Greece, Memoirs of the Second World War, Boston, Houghton Mifflin Books, 1991.

Cummins, Chris: “Operation Gertrude: The Germen Invasion Of Turkey”, World At War Magazine, S.49, 2016.

Çınar, Burak: “İkinci Dünya Savaşı'nda Almanya’nın İki Cepheli Savaş Sorunu”, Güvenlik Stratejileri Dergisi, C.10, S.20, İstanbul, Ocak 2014.

Çınar, Burak: “İkinci Dünya Savaşı’nda Kırım Yarımadası'na Düzenlenen Harekatlar ve Kırım’ın Stratejik Değeri”, Tarih Araştırmaları Dergisi, C.38, S.66, Ankara, 2019.

Danacıŏlu, H. Esra: “Mefkure Faciası”, Toplumsal Tarih Dergisi, S.44, 1997.

Deniz Kuvvetleri Komutanlığı, Denizlerin Koruyucularl, Ankara, 2003.

Deniz, Muzaffer: "Hitler Dönemi Türk-Alman Anlaşmaları", The Journal of Science (SOBIDER), Y.2, S.2, Mart 2015.

Dowling, Timothy C.: Russia at War, ABC-CLIO Publishing, 2014.

Dönitz, Kraus Karl: Goeben ve Breslau'nun Deniz Seferi, çev. Mustafa H. Cümbüş, Ankara, Orient Yayınları, 2013.

Enders, Gerd: Deutsche U-Boote zum Schwarzen Meer. 1942-1944. Eine Reise ohne Wiederkehr, Hamburg, Mittler, 1997.

Erden, Ali Fuad: İsmet Inönü, Ankara, Bilgi Yayınevi, 1999.

Gilbert, Martin: Churchill, İstanbul, Türkiye İş Bankası Kültür Yayınları, 2011.

Glantz, David M.: Operation Barbarossa Hitler's Invasion of Russia 1941, Port Stroud, The History Press, 2011.

Gröner, Erich-Jung, Dieter-Maass, Martin: German Warships 1815-1945: U-boats and Mine Warfare Vessels, çev. Keith Thomas, Rachel Magowan, London, Conway Maritime Press, 1991. 
Gürbüz, Kahraman: “İkinci Dünya Savaşı’nda Balkanlardaki Gelişmeler ve Türkiye’nin Tutumu”, Uludă̆ Üniversitesi Fen-Edebiyat Fakültesi Sosyal Bilimler Dergisi, C.8, S.13, Bahar 2007.

Hadley Michael L.: “Grand Admiral Dönitz (1891-1980): A Dramatic Key To The Man Behind The Mask", The Northern Mariner/Le Marin du Nord, C.X, No.2, Nisan 2000.

Haffner, Sebastian: Hitler Üzerine Notlar, çev. Hulki Demirel, İstanbul, İletişim Yayınlar1, 2019.

Halpern, Paul G.: A Naval History of World War I, New York, Routledge Press, 1919.

Higgins, Trumbull: Winston Churchill and the Second Front, New York, Oxford University Press, 1957.

Kalaycıŏlu, Ömer: Denizaltı ve Filomuz, İstanbul, Deniz Kuvvetleri Komutanlığı, 1990. Kearns, Gerry: "Imperial Geopolitics: Geopolitical Visions at the Dawn of the American Century", Companion to Political Geography, Oxford, Blackwell, 2003.

Kemp, Paul: U-Boats Destroyed-German Submarine Losses in the World Wars, London, Arms\&Armour, 1999.

Keser, Ulvi: “Arşiv Belgeleri Işığında İkinci Dünya Savaşı Sürecinde Türkiye'de Mülteciler ve Esirler Sorunu", Çağdaş Türkiye Tarihi Araştırmaları Dergisi, C.VII, S.18-19, İzmir, 2009.

Koçak, Cemil: Türk-Alman İlişkileri 1923-1939. İki Savaş Arasındaki Dönemde Siyasal, Kültürel, Askeri ve Ekonomik Illişkiler, Ankara, Türk Tarih Kurumu Basımevi, 1991. Liddel, Hart B. H.: II. Dünya Savaşı Tarihi, C.I, çev. Kerim Bağrıaçık, İstanbul, Yapı Kredi Yayınları, 1998.

Lucas, James: Reich! World War II Through German Eyes, London, Grafton Books, 1990 .

Manstein, Erich von: Kaybedilen Zaferler, İstanbul, Kara Kuvvetleri Komutanlığ1 İstanbul Askeri Basımevi, 1962.

Metel, Raşit: Türk Denizaltıcılık Tarihi-I (1960-1970), İstanbul, 1970.

Muşmal, Hüseyin-Gümüş, Hasret: “II. Dünya Savaşı Yıllarında Beyşehir'de Bir Enterne Kampı (Hitlerin Askerleri Beyşehir'de)”, Tarihin Peşinde-Uluslararası Tarih ve Sosyal Araştırmalar Dergisi, S.24, 2020.

Nesbit, Roy Conyers: Ultra Versus U-Boats, Pen\&Sword Military, South Yorkshire, 2008 .

Özlü, Hüsnü: Ikkinci Dünya Savaşı'ndan Günümüze Türkiye'de Savunma Sanayii'nin Gelişimi 1939-1990, İzmir, Dokuz Eylül Üniversitesi, Atatürk İlkeleri ve İnkılap Tarihi Enstitüsü, Yayımlanmamış Doktora Tezi, 2006. 
Peterson, Edward N.: An Analytical History of World War II (Volume 1), New York, Peter Lang, 1995.

Read, J.: Mülteciler Meselesinin Mahiyeti ve Alınmakta Olan Tedbirler, çev. Gülgin Gönenç, Ankara, Türkiye Amme İdaresi Enstitüsü, 1959.

Roessler, Eberhard: Die Unterseeboote der Kaiserlichen Marine, Bonn, Bernard\&Graefe, 1997.

Schroeder, Joachim: Die U-Boote des Kaisers, Bonn, Bernard\&Graefe, 2002.

Soysal, İsmail: Türkiye’nin Siyasal Antlaşmaları, (1920-1945), C.I, Ankara, Türk Tarih Kurumu Yayınları, 2000.

Toy, Mutlu: Savaşta ve Barışta Türkiye’nin Savunması Açısından Denizaltı Gücünün Stratejik Etkileri, Gebze Yüksek Teknoloji Enstitüsü, Sosyal Bilimler Enstitüsü Strateji Bilimi Anabilim Dalı, Yayımlanmamış Yüksek Lisans Tezi, 2007.

Yaman, Ahmet Emin: “II. Dünya Savaşı'nda Türkiye’de Askeri Mülteciler ve Gözaltı Kampları (1941-1942)", Tarih Araştırmaları Dergisi, C.22, S.33, 2003.

\section{Elektronik Kaynaklar}

"U20 Batık Denizaltı-Sakarya”, 8 Şubat 2013 (Çevrimiçi), https://www.kulturportali. gov.tr/turkiye/sakarya/gezilecekyer/u20-batik-denizalti, 07.10.2020.

“Şile-Ağva Açıklarında II. Dünya Savaşı’ndan Kalma Denizaltı Bulundu”, 1 Şubat 2019 (Çevrimiçi), https://www.ntv.com.tr/galeri/sanat/sile-agva-aciklarinda-2-dunyasavasindan-kalma-denizalti-bulundu,N67sn9kcwU-yOax-JuMOpw, 08.10.2020.

"Hitler'in Kayıp Filosu Karadeniz Kıyımızda”, 4 Şubat 2008 (Çevrimiçi), https://www. hurriyet.com.tr/gundem/hitler-in-kayip-filosu-karadeniz-kiyilarimizda-8160783, 08.10.2020.

"U-19 Uboat Submarine Wreck" (Çevrimiçi), http://kaanaltin.com/uboat19eng.html, 13.10.2020.

"U-20 Uboat Submarine Wreck" (Çevrimiçi), http://kaanaltin.com/uboat20eng.html, 13.10.2020.

"U-23 Uboat Submarine Wreck" (Çevrimiçi), http://kaanaltin.com/uboat23eng.html, 13.10.2020. 


\section{EKLER}

Ek-1: U-19 battı̆ğında muhtemel mürettebat ${ }^{104}$

\begin{tabular}{|c|c|c|c|}
\hline Gemi Türü & Denizalt1 & Kızağa Konulduğu Yer & Germaniawerft Kiel \\
\hline Gemi Kodu & U-19 & Hizmete Giriși & 2 Şubat 1935 \\
\hline Gemi Tipi & II B & $\begin{array}{l}\text { İş Birliği Yaptığı } \\
\text { Filotilla }\end{array}$ & $\begin{array}{l}\text { 1. U-boat, 22. U-boat, 24. U-boat ve } 30 . \\
\text { U-boat filotillası ile karakol faaliyeti } \\
\text { yürütmüştür. }\end{array}$ \\
\hline Mürettebat & $\begin{array}{l}25 \text { personel } \\
\text { (3 Subay) }\end{array}$ & Mühimmat & $\begin{array}{l}\text { Üç ileri torpido } 6 \times 21 \text { tüp kanallı ve } 1 \times 20 \mathrm{~mm} \\
\text { AA ön güverte silahı }\end{array}$ \\
\hline Kimlik No. & M 23036 & Komutanlar & $\begin{array}{l}\text { Josef Cremer, Fritz Hauffe, Josef Landmeyer, } \\
\text { Karl-Heinz Lange, Emil Langer, Frederich } \\
\text { Mossinger, Sherbaum, Hans Shön, Richard } \\
\text { Knapp, Timm Thode, Hans Menckel, } \\
\text { Willihem Müller-Amecke, Willy Ohlenberg, } \\
\text { Hubert Verpoorten }\end{array}$ \\
\hline Suya İndirilişi & 21 Aralık 1935 & Derinlik & $80 \mathrm{~m}$ \\
\hline Sira Numarası & 549 & Batırılış & 10 Eylül 1944 Karadeniz açıkları \\
\hline
\end{tabular}

104 Patrick Beesly, Room 40: British Naval Intelligence 1914-1918, London, H Hamilton Press, 1982; Paul G. Halpern, A Naval History of World War I, New York, Routledge Press, 1919; Eberhard Roessler, Die Unterseeboote der Kaiserlichen Marine, Bonn, Bernard\&Graefe, 1997; Joachim Schroeder, Die U-Boote des Kaisers, Bonn, Bernard\&Graefe, 2002; "U-19 Uboat Submarine Wreck" (Çevrimiçi), http://kaanaltin.com/uboat19eng.html, 13.10.2020. 
Ek-2: U-23 battı̆̆1nda muhtemel mürettebat ${ }^{105}$

\begin{tabular}{|c|c|c|c|}
\hline Gemi Türü & Denizaltı & Kızağa Konulduğu Yer & Germaniawerft Kiel \\
\hline Gemi Kodu & $\mathrm{U}-23$ & Hizmete Girişi & 2 Şubat 1935 \\
\hline Gemi Tipi & II B & $\begin{array}{l}\text { İş Birliği Yaptığı } \\
\text { Filotilla }\end{array}$ & $\begin{array}{l}\text { 1. U-boat, 21. U-boat, } 30 \text {. U-boat, } \\
\text { filotillası ile karakol faaliyeti } \\
\text { yürütmüştür. }\end{array}$ \\
\hline Mürettebat & $\begin{array}{l}25 \text { personel } \\
\text { ( } 3 \text { Subay) }\end{array}$ & Mühimmat & $\begin{array}{l}3 \times 53.3 \mathrm{~cm}(21 \mathrm{in}) \text { torpido tüpü, } \\
5 \times \text { torpido veya } 12 \text { TMA veya } 18 \\
\text { TMA mayınları } \\
1 \times 2 \mathrm{~cm}(0.79 \text { in }) \text { uçaksavar makinalı } \\
\text { tüfeği }\end{array}$ \\
\hline Kimlik No & M01 984 & Komutanlar & $\begin{array}{l}\text { Hans Gassler, Karl-Ederhard } \\
\text { Eggert, Karl Geuting, Hans Georg } \\
\text { Heidelberg, Eward Hrabak, Otto } \\
\text { Köhler, Horst Lemke, Walter } \\
\text { Limberger, Helmut Reinhard, Kurt } \\
\text { Shermus, Karl Shneider, Arno } \\
\text { Schönherr, Willy Schöttker, Werner } \\
\text { Shubert, Fritz Schwarz, Willheim } \\
\text { Brozulat, Horst Bahr } \\
\text { Heinrich Bierwirt, Herbert } \\
\text { Bernsdolf, Walter Dohrn, Herbert } \\
\text { Seidel, Georg Stober, Herbert } \\
\text { Theuring, Heinz Vogt, Helmut } \\
\text { Welzel, Gustav Wolf, Herbert } \\
\text { Czekala, Rudolf Arendt. }\end{array}$ \\
\hline Suya İndirilişi & 11 Nisan 1936 & Derinlik & $80 \mathrm{~m}$ \\
\hline Sıra Numarası & 553 & Batırılış & 10 Eylül 1944 Karadeniz açıkları \\
\hline
\end{tabular}

105 Rainer Busch-Hans-Joachim Röll, German U-Boat Commanders Of World War II: A Biographical Dictionary, translated by Geoffrey Brooks, London\&Annapolis, Greenhill Books\&Naval Institute Press, 1999; Erich Gröner-Dieter Jung-Martin Maass, German Warships 1815-1945: U-boats and Mine Warfare Vessels, çev. Keith Thomas, Rachel Magowan, London, Conway Maritime Press, 1991; "U-23 Uboat Submarine Wreck” (Çevrimiçi), http://kaanaltin.com/ uboat23eng.html, 13.10.2020. 
Ek-3: U-20 battığında muhtemel mürettebat ${ }^{106}$

\begin{tabular}{|c|c|c|c|}
\hline Gemi Türü & Denizaltı & Kızağa Konulduğu Yer & Germaniawerft Kiel \\
\hline Gemi Kodu & U-20 & Hizmete Girişi & 2 Şubat 1935 \\
\hline Gemi Tipi & II B & $\begin{array}{l}\text { İş Birliği Yaptığı } \\
\text { Filotilla }\end{array}$ & $\begin{array}{l}\text { 1. U-boat, 3. U-boat, 21. U-boat, } 30 . \\
\text { U-boat, filotillası ile karakol faaliyeti } \\
\text { yürütmüştür. }\end{array}$ \\
\hline Mürettebat & $\begin{array}{l}25 \text { personel } \\
\text { ( } 3 \text { Subay) }\end{array}$ & Mühimmat & $\begin{array}{l}3 \times 53.3 \mathrm{~cm}(21 \text { in) torpido tüpü, } \\
5 \times \text { torpido veya } 12 \text { TMA veya } 18 \\
\text { TMA mayınları } \\
1 \times 2 \mathrm{~cm}(0.79 \text { in }) \text { uçaksavar makinalı } \\
\text { tüfeği }\end{array}$ \\
\hline Kimlik No & M29 271 & Komutanlar & $\begin{array}{l}\text { Denizaltı Kpt. Hans Eckermann, } \\
\text { Willhelm Hennings, Karl Grafen, } \\
\text { Alfred Borries, Hans Johaim } \\
\text { Büchler, Dirks, Peter Düster, Josef } \\
\text { Dylla, Otto Frank, Edgra Freger, } \\
\text { Gerhard Gradias, Willy Hartmann, } \\
\text { Rolf Kalbreyer, Hans Klütsch, } \\
\text { Wolfgang Gerhard Leithoff, Sippel, } \\
\text { Michael Watteler }\end{array}$ \\
\hline Suya İndiriliși & 1 Şubat 1936 & Derinlik & $80 \mathrm{~m}$ \\
\hline Sira Numarası & 550 & Batırılıș & 10 Eylül 1944 Karadeniz açıkları \\
\hline
\end{tabular}

106 Paul Kemp, U-Boats Destroyed-German Submarine Losses in the World Wars, London, Arms\&Armour, 1999; Gerd Enders, Deutsche U-Boote zum Schwarzen Meer. 1942-1944. Eine Reise ohne Wiederkehr, Hamburg, Mittler, 1997; "U-20 Uboat Submarine Wreck" (Çevrimiçi), http://kaanaltin.com/uboat20eng.html, 13.10.2020. 